\title{
Functionalization of diazines and benzo derivatives through deprotonated intermediates
}

\author{
Floris Chevallier and Florence Mongin
}

Received (in XXX, XXX) 1st January 2007, Accepted 1st January 2007

${ }_{5}$ First published on the web 1st January 2007

DOI: 10.1039/b000000x

Diazines and benzo derivatives can undergo deprotonative metalation provided that the base is properly chosen. Indeed, these substrates are prone to nucleophilic additions or substitutions in relation to lower energy levels of their LUMOs. Metalation reactions of a large range of substrates

10 can be performed using hindered lithium dialkylamides such as lithium diisopropylamide or above all lithium 2,2,6,6-tetramethylpiperidide. New bases including magnesates and zincates have recently emerged and proved convenient to allow reactions of more sensitive substrates. Subsequent reactions with electrophiles open an entry to a great variety of building blocks, notably for the synthesis of biologically active compounds ( 83 references).

\section{Introduction}

Diazines belong to the most important heterocycles containing nitrogen. Many natural products are derived from pyrimidine. Thymine, cytosine and uracil are for example important as 20 building blocks for the nucleic acids, orotic acid is the key compound in the biosynthesis of almost all naturally occurring pyrimidine derivatives, and aneurin (thiamine, vitamin B1) is present in yeast, in rice polishing and in various cereals. A few pyrimidine antibiotics possess potent antitumor properties 25 (e.g. bleomycin). Several natural products contain the quinazoline structure; examples are the quinazoline alcaloids isolated from rutaceae (e.g., arborine). In addition, the pyrimidine core is present in many pharmaceuticals such as trimethoprim, sulfadiazine, pyrimethamine, hexetidine, 530 fluorouracil and zidovudin, as well as in herbicides (e.g., bensulfuronmethyl), and the quinazoline ring occurs in pharmaceuticals such as methaqualone, quinethazone, proquazone and prazosin. ${ }^{1}$

Few natural compounds contain the pyridazine ring. ${ }_{35}$ Derivatives such as pyrazon and pyridaben show biological activity and are applied as herbicides and anthelmintics. In contrast, pyrazines occur frequently as flavor constituents in foodstuffs that undergo heating (coffee, meat...). Alkylpyrazines also act as ant pheromons. Since a high degree 40 of structural complexity characterizes such compounds, there is a need for highly selective, flexible and efficient synthetic methods. ${ }^{1}$

Pyridazines can be prepared using one of the following approaches: (1) cyclocondensation reactions between 1,445 dicarbonyl compounds and hydrazine, (2) cyclocondensation reactions between 1,2-diketones, reactive $\alpha$-methylene esters and hydrazine ${ }^{2}$ and (3) cycloaddition/cycloreversion sequences. ${ }^{3}$ Bare pyridazine is produced from maleic anhydride: reaction of the latter with hydrazine yields maleic 50 hydrazide which, upon treatment with $\mathrm{POCl}_{3} / \mathrm{PCl}_{5}$, affords 3,6-dichloropyridazine, a precursor of pyridazine (reductive dehalogenation using catalytic hydrogenation). Cinnolines can be generated by intramolecular cyclization of ortho-alkenyl or ortho-alkynyl aryldiazonium salts, and phthalazines by 55 cyclocondensation of ortho-diacylbenzenes with hydrazine. ${ }^{1}$

Pyrimidines are mainly synthesized by cyclocondensation reactions of 1,3-dicarbonyl compounds (or other 1,3-biselectrophiles) with amidines, ureas, thioureas, guanidines and urethanes. ${ }^{4}$ Phosphazenes containing an amidine moiety can ${ }_{60}$ be converted to pyrimidines by reaction with $\alpha, \beta$-unsaturated aldehydes (aza-Wittig reaction) followed by oxidative electrocyclic ring closure. ${ }^{5}$ Condensation of 1,1,3,3tetraethoxypropane with formamide furnishes bare pyrimidine. ${ }^{6}$ Several methods exist to access to quinazolines. ${ }^{1}$

65 Pyrazines are generally produced by self-condensation of $\alpha$-amino carbonyl compounds and the combination of $\alpha$ diketones with vicinal diamines followed by dehydrogenation, ${ }^{7}$ but these methods disappoint in the preparation of unsymmetrically substituted pyrazines. 70 Alternative syntheses include cyclizing aza-Wittig reactions of two molecules of $\alpha$-phosphazinyl ketones or oxidation of dioxopiperazines. Few regioselective syntheses exist. ${ }^{8}$ Similar approaches are described to reach quinoxalines. ${ }^{1}$

The reactions of diazines are determined by the presence of 75 the ring $\mathrm{N}$ atoms. The latter are attacked by electrophiles, but deactivate the ring $\mathrm{C}$ atoms. Hence, few $\mathrm{S}_{\mathrm{E}} \mathrm{Ar}$ processes take place, and if so, in moderate yields. Diazines are more reactive than pyridine towards nucleophiles (addition and substitution reactions). Concerning benzodiazines, $\mathrm{S}_{\mathrm{E}} \mathrm{Ar}$ 80 reactions take place, when possible, on the benzene ring, whereas nucleophilic substitutions occur in the diazine ring, particularly if substituted by halogens. ${ }^{1}$

Site selectivity could be easily achieved of course if the electrophile could react with a specific diazinylmetal rather 85 than with the unmodified heterocycle. Non-deprotonative accesses to diazinylmetals such as halogen/metal exchange have been developed, ${ }^{9}$ but the problem is only deferred since 
the preparation of bromo- and polybromodiazines that could be used as substrates is generally not trivial. The metalation (hydrogen/metal permutation) avoids the use of heavy halogen-substituted diazines.

5 The acidities of hydrogens in diazines are related to the less highly-conjugated p orbitals (decrease in aromaticity) in the ring when compared to azines (and of course benzene). The $\mathrm{p} K_{\mathrm{a}}$ values for $\mathrm{C}-\mathrm{H}$ bonds of numerous aromatic heterocyclic compounds including diazines have been recently 10 calculated. ${ }^{10}$ The strongest acidity on diazines was estimated to be the 4-position of pyridazine (31.1), and the weakest one the 2-position of pyrimidine (40.0) (Scheme 1).<smiles>c1cc[14c]cc1</smiles><smiles>c1ccccc1</smiles><smiles></smiles>
pyridazine pyrimidine<smiles>c1cnccn1</smiles>
pyrazine
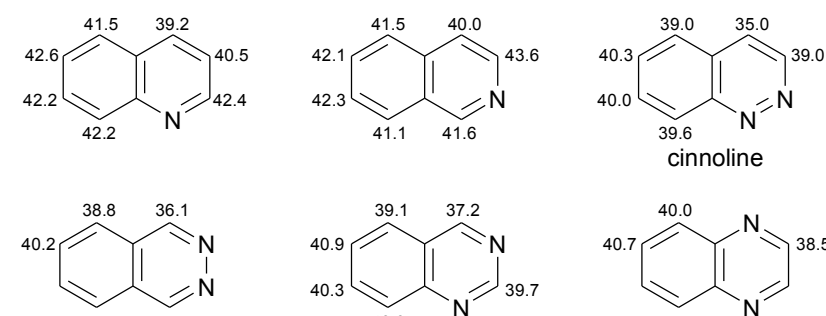

phthalazine

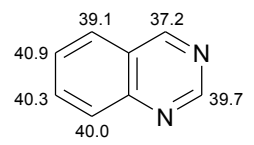

quinazoline

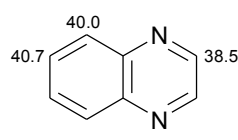

quinoxaline

Scheme 1 Estimated $\mathrm{p} K_{\mathrm{a}}$ values for $\mathrm{C}-\mathrm{H}$ bonds.

15 Unlike five-membered heterocycles, for which protons adjacent to heteroatom have the strongest acidity, sixmembered heterocycles have the weakest acidic protons adjacent to nitrogens, a result of the more important repulsion between the lone electron pair of nitrogen and the negative 20 charge of the carbanion for the latter, due to the smaller angle between the two electron clouds. ${ }^{10}$

As a consequence, using the nonmetallic ${ }^{t} \mathrm{Bu}-\mathrm{P} 4$ organic base $\left(\mathrm{p} K_{a}=42.7\right.$ in $\left.\mathrm{MeCN}\right)$, which is highly chemoselective and proceeds without coordination to ring nitrogen, pyridazine 25 and pyrimidine are regioselectively deprotonated at the most acidic 4- and 5-positions, respectively, as evidenced by trapping by a carbonylated compound (Scheme 2). ${ }^{11}$<smiles>c1ccncc1</smiles>
$\underset{73 \%}{\stackrel{\text { [a] }}{\longrightarrow}}$<smiles>CC(C)CC(O)c1ccnnc1</smiles><smiles>CC(C)(C)CC(O)c1cncnc1</smiles>

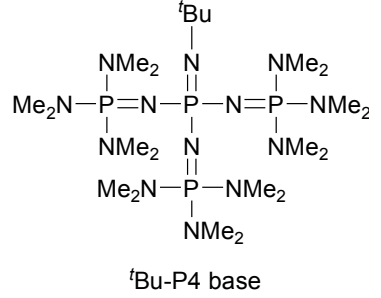

Scheme 2 Deprotonative functionalization of pyridazine and pyrimidine 30 using ${ }^{t} \mathrm{Bu}-\mathrm{P} 4$ base. Reaction conditions: [a] ${ }^{t} \mathrm{BuCHO},{ }^{t} \mathrm{Bu}-\mathrm{P} 4, \mathrm{ZnI}_{2}$, toluene, $-75^{\circ} \mathrm{C}$ to $\mathrm{rt}$; [b] ${ }^{t} \mathrm{BuCHO},{ }^{t} \mathrm{Bu}-\mathrm{P} 4, \mathrm{ZnI}_{2}$, toluene, $-75^{\circ} \mathrm{C}$ to rt. deficient aza-heterocycles, the regioselectivity of the reaction is generally different because of additional effects. ${ }^{12}$ ${ }_{35}$ Coordination of the/a ring nitrogen to the metal (particularly in the absence of a chelating solvent such as THF) causes the disaggregation of the base (which becomes more reactive), increases the electron-withdrawing effect of the nitrogen, and (thus) favors the deprotonation at an adjacent position. Since 40 diazines (pyridazine: $\mathrm{p} K_{a}=2.3$, pyrimidine: $\mathrm{p} K_{a}=1.3$, pyrazine: $\left.\mathrm{p} K_{a}=0.4\right)$ are less basic than pyridine $\left(\mathrm{p} K_{a}=5.2\right)$, this effect is supposed to be less important. In addition, it should be noted that the compound lithiated at the nitrogen adjacent position is on the one hand stabilized by the electron45 withdrawing effect of the nitrogen(s), but on the other hand destabilized by electronic repulsion between the carbanion and the lone pair of the adjacent nitrogen.

The electron-withdrawing effect of the diazine nitrogens decreases the energy level of the LUMO of these substrates 50 and makes them more sensitive to nucleophilic addition. ${ }^{12 a, 13}$ As a consequence, "soft" alkyllithiums, which are strong bases $\left(\mathrm{p} K_{\mathrm{a}} \sim 40-50\right)$, have to be avoided since they easily add nucleophilically to the diazine ring, even at low temperatures. It is advisable to rely upon the "harder", though less basic 55 lithium diisopropylamide (LDA, $\left.\mathrm{p} K_{\mathrm{a}}=35.7\right)$ and lithium 2,2,6,6-tetramethylpiperidide (LTMP, $\mathrm{p} K_{\mathrm{a}}=37.3$ ) to effect deprotonation. Nevertheless, this still happens to be difficult with bare heterocycles, for which formation of dimeric products -either by addition of lithiated substrate to another 60 molecule ${ }^{14}$ or by dimerization of "radical anions"- can hardly be avoided. ${ }^{15}$ When compared to pyridine, nitrogens of diazines are less chelating but the ring hydrogens are more acidic. For these reasons, reactions should be less regioselective.

65 Using lithium amides as the bases, the reaction is usually under thermodynamic control, and the regioselectivity observed is the result of different effects such as stabilization by the electron-withdrawing effect of the ring nitrogens and destabilization by electronic repulsion between the carbanion 70 and the lone pair of the adjacent ring nitrogen. These effects are modulated by the aggregation state of the lithium species, which largely depends on the solvent, for example. A rationalization of the regioselectivity becomes more complicated when substituted diazines are concerned. As the 75 ring nitrogen, the substituent can stabilize by inductive electron-withdrawing effect. It can also chelate the Lewis acidic metal of the base, an effect that is important for the few reactions carried out under kinetic control using alkyllithiums since it allows the disaggregation of the base, reinforces the 80 electron-withdrawing effect of the substituent and increases the proximity effect of the complexed base. Under thermodynamic control, unlike the ring nitrogen the substituent can stabilize the metalated substrate by chelation, which reinforces the electron-withdrawing effect. Steric 85 hindrance caused by the substituent has an impact on the outcome of the reaction too. Some of these effects could explain the regioselectivity observed in the examples depicted in Scheme 3. ${ }^{16}$

When metallic bases are employed to deprotonate $\pi$ - 
<smiles>c1ccc(-c2cnccn2)nc1</smiles>

$$
\underset{72 \%}{\stackrel{[a, b]}{\rightleftarrows}}
$$<smiles>CC(C)(C)c1nccnc1-c1ccccn1</smiles><smiles>c1ccc(-c2ccc(-c3ccccn3)nn2)cc1</smiles><smiles>COc1ccc(C(O)c2cc(-c3ccccc3)nnc2-c2ccccc2)cc1</smiles>

Scheme 3 Deprotonative functionalization of (2-pyridyl)pyrazine and 3phenyl-6-(2-pyridyl)pyridazine. Reaction conditions: [a] LTMP, THF, $-100{ }^{\circ} \mathrm{C}, 15 \mathrm{~min}$; [b] Electrophile: $\mathrm{Bu}_{3} \mathrm{SnCl}$; [c] LTMP, THF, $-78{ }^{\circ} \mathrm{C}, 15$ 5 min; [d] Electrophile: 4- $\mathrm{MeOC}_{6} \mathrm{H}_{4} \mathrm{CHO}$; [e] hydrolysis.

\section{Metalation of pyridazines, cinnolines and phthalazines}

2.1 Metalation of bare pyridazine and long range activated cinnolines

${ }_{10}$ Few attempts to deprotonate bare pyridazine have been described in the literature. Monometalation next to nitrogen was found possible with 4 molar equiv. of LTMP and very short reaction times at $-75{ }^{\circ} \mathrm{C}$, a result evidenced by interception with deuterium chloride, benzaldehyde, 15 acetaldehyde or elemental iodine to give the functionalized pyridazines 1 though in 16 to $32 \%$ yields. When tertbutyldimethylsilyl chloride was used instead, the 4-substituted pyridazine was produced in a very low $10 \%$ yield. ${ }^{17}$ Using an in situ prepared mixture of $\mathrm{ZnCl}_{2}$.TMEDA ( 0.5 equiv.) and 20 LTMP (1.5 equiv.) in THF containing 5 extra equiv. of TMEDA, the zincation could be performed at reflux to give after quenching with elemental iodine a 83:9:8 mixture of 3iodo, 4-iodo and 3,5-diiodopyridazine, respectively, from which the main compound was isolated in $66 \%$ yield $^{18}$ 25 (Scheme 4).

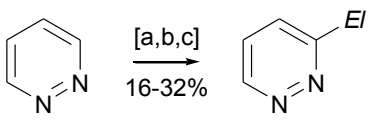

1

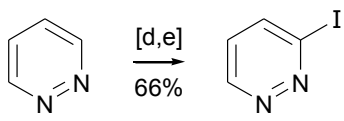

Scheme 4 Deprotonative functionalization of pyridazine. Reaction conditions: [a] LTMP, THF, $-75^{\circ} \mathrm{C}, 6 \mathrm{~min}$; [b] Electrophile $\{$ El $\}$ : DCl $\{\mathrm{D}\}, \quad \mathrm{PhCHO}\{\mathrm{CH}(\mathrm{OH}) \mathrm{Ph}\}, \quad \mathrm{MeCHO}\{\mathrm{CH}(\mathrm{OH}) \mathrm{Me}\}, \mathrm{I}_{2}\{\mathrm{I}\} ; \quad[\mathrm{c}]$ 30 hydrolysis; [d] $\mathrm{ZnCl}_{2}$.TMEDA, LTMP, TMEDA, THF, reflux, 2 h; [e] Electrophile: $\mathrm{I}_{2}$.

Provided that their pyridazine ring are completely substituted, cinnolines can be deprotonated on the benzene ring, next to the ring nitrogen (Scheme 5). ${ }^{19}$ Interception with 35 iodine allowed subsequent arylation through Suzuki or Stille cross-couplings.
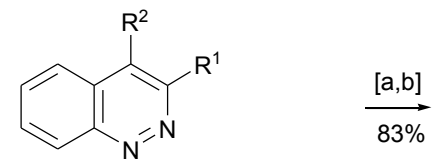

$\mathrm{R}^{1}=\mathrm{OMe}, \mathrm{R}^{2}=\mathrm{Cl}$

$\mathrm{R}^{1}=\mathrm{SiMe}_{3}, \mathrm{R}^{2}=4-\mathrm{MeOC}_{6} \mathrm{H}_{4}$

$\mathrm{R}^{1}=\mathrm{SiMe}_{3}, \mathrm{R}^{2}=4-\mathrm{F}_{3} \mathrm{CC}_{6} \mathrm{H}_{4}$<smiles>[R]c1nnc2c(I)cccc2c1[R]</smiles>

$83 \%$

$72 \%$

$88 \%$

Scheme 5 Deprotonative functionalization of 4-chloro-3-methoxy-, 4-(4methoxyphenyl)-3-trimethylsilyl- and 4-(4-trifluoromethylphenyl)-340 trimethylsilylcinnoline. Reaction conditions: [a] LTMP, THF, $-75{ }^{\circ} \mathrm{C}, 30$ $\min$ to $1 \mathrm{~h} ;[\mathrm{b}]$ Electrophile: $\mathrm{I}_{2}$.

In general, the substituents help in steering the metal to the targeted location.

\subsection{Metalation of halo- pyridazines, cinnolines and} 45 phthalazines

Metalation of 3-bromo-6-phenylpyridazine was achieved using a twofold excess of LDA in THF at $-100{ }^{\circ} \mathrm{C}$. The complete regioselectivity next to the bromo group was inferred by trapping the lithio compound with 4-anisaldehyde $50(84 \%$ yield $) .^{20}$

Starting from 3,6-dichloropyridazine, the LTMP-mediated deprotonation proceeded in $\mathrm{THF}$ at $-70{ }^{\circ} \mathrm{C}$, and led to the 4substituted derivatives $\mathbf{2}$ in variable yields after subsequent trapping (Scheme 6). ${ }^{21}$<smiles>Clc1ccc(Cl)nn1</smiles>

Scheme 6 Deprotonative functionalization of 3,6-dichloropyridazine Reaction conditions: [a] LTMP, THF, $-70{ }^{\circ} \mathrm{C}, 1.5 \mathrm{~h}$; [b] Electrophile $\{E l\}: \mathrm{MeCHO}\{\mathrm{CH}(\mathrm{OH}) \mathrm{Me}\}, \mathrm{PhCHO}\{\mathrm{CH}(\mathrm{OH}) \mathrm{Ph}\}, 4-\mathrm{MeOC}_{6} \mathrm{H}_{4} \mathrm{CHO}$ $\left\{\mathrm{CH}(\mathrm{OH})\left(4-\mathrm{MeOC}_{6} \mathrm{H}_{4}\right)\right\}, \quad 2-\mathrm{MeOC}_{6} \mathrm{H}_{4} \mathrm{CHO} \quad\left\{\mathrm{CH}(\mathrm{OH})\left(2-\mathrm{MeOC}_{6} \mathrm{H}_{4}\right)\right\}$, ${ }_{60} \mathrm{PhCONMe}_{2}\{\mathrm{COPh}\}, \mathrm{Me}_{3} \mathrm{SiCl}\left\{\mathrm{SiMe}_{3}\right\}, \mathrm{HCONMe}_{2}\{\mathrm{CHO}\}, \mathrm{Ph}_{2} \mathrm{CO}$ $\left\{\mathrm{C}(\mathrm{OH}) \mathrm{Ph}_{2}\right\}, \mathrm{I}_{2}\{\mathrm{I}\} ;[\mathrm{c}]$ hydrolysis.

Replacing one of the chloro groups by another substituent offered challenging model compounds to test the regioselectivity of the reaction. With 3-chloro-665 fluoropyridazine, metalation using either LDA or LTMP in THF at low temperature took place next to the smaller halogen. ${ }^{22}$ With a pivaloylamino group instead, reaction using LTMP in THF at $-70{ }^{\circ} \mathrm{C}$ occurred randomly whereas employing LDA (4 equiv.) exclusively afforded deprotonation 70 at the position adjacent to the halogen, providing after trapping with acetaldehyde or benzaldehyde the expected alcohols in $68-82 \%$ yields. $^{23}$

The situation became more complex with 3-chloro-6methoxypyridazine. The 4- (next to the chloro group) and 575 (next to the methoxy group) substituted derivatives were produced in a 20:80 ratio after reaction with LTMP in THF at $-70{ }^{\circ} \mathrm{C}$ followed by trapping with iodomethane. ${ }^{24}$ Recourse to very hindered bases such as lithium $N$-tert-butyl- $N$-(1isopropylpentyl)amide $\left(\mathrm{LB}_{1}\right)$ allowed to reach a 1:99 ratio 80 using the same electrophile. ${ }^{25}$ It was noted that using the in 
situ trapping method metalation also occurred regioselectively next to the methoxy group. ${ }^{26}$

When one of the chloro groups was replaced with a methoxyethoxy, using LDA or LTMP in THF at $-70{ }^{\circ} \mathrm{C}$ gave 5 a mixture of both possible lithio compouds ${ }^{23}$ (Scheme 7).<smiles></smiles>

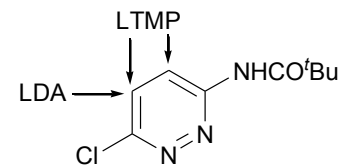<smiles>COc1nnc(Cl)c([Al])c1C(Br)(Br)Br</smiles><smiles></smiles>

Scheme 7 Regioselectivity of the metalation of 3-chloro-6-fluoropyridazine, $N$-pivaloyl protected 3-amino-6-chloropyridazine, 3-chloro-6-methoxypyridazine and 3-chloro-6-(methoxyethoxy)pyridazine using hindered 10 lithium amides.

Functionalization of 3- and 4-chlorocinnoline at the vacant 4- and 3-position, respectively, was achieved in satisfying yields through deprotonation using LTMP in THF at low temperatures, to furnish the compounds $\mathbf{3}$ and $\mathbf{4}$, respectively 15 (Scheme 8). ${ }^{19 a}$

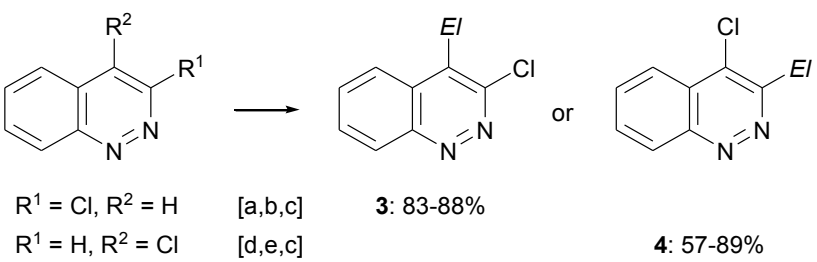

Scheme 8 Deprotonative functionalization of 3- and 4-chlorocinnoline. Reaction conditions: [a] LTMP, THF, $-75^{\circ} \mathrm{C}, 2 \mathrm{~h}$; [b] Electrophile $\{E l\}$ : $\mathrm{MeCHO}\{\mathrm{CH}(\mathrm{OH}) \mathrm{Me}\}, \mathrm{PhCHO}\{\mathrm{CH}(\mathrm{OH}) \mathrm{Ph}\}$; [c] hydrolysis; [d] LDA, $20 \mathrm{THF},-75{ }^{\circ} \mathrm{C}, 30 \mathrm{~min}$; [e] Electrophile $\{$ El $\}$ : $\mathrm{MeCHO}\{\mathrm{CH}(\mathrm{OH}) \mathrm{Me}\}$, $\mathrm{PhCHO}\{\mathrm{CH}(\mathrm{OH}) \mathrm{Ph}\}, 4-\mathrm{MeOC}_{6} \mathrm{H}_{4} \mathrm{CHO}\left\{\mathrm{CH}(\mathrm{OH})\left(4-\mathrm{MeOC}_{6} \mathrm{H}_{4}\right)\right\}$, MeI $\{\mathrm{Me}\}, \mathrm{I}_{2}\{\mathrm{I}\}, \mathrm{CO}_{2}\left\{\mathrm{CO}_{2} \mathrm{H}\right\}$.

Butyllithium surprisingly gave better results than LTMP when used to functionalize 6-chloro-1,425 dimethoxyphthalazine. Metalation solely occurred at the 7position, leading to the compounds $\mathbf{5}$. In the absence of chloro group, the addition product $\mathbf{6}$ was formed instead (Scheme 9). ${ }^{27}$<smiles>[R]c1ccc2c(OC)nnc(OC)c2c1</smiles><smiles>[Te][TeH]</smiles><smiles>CCc1cc2c(OC)nnc(OC)c2cc1Cl</smiles>

5

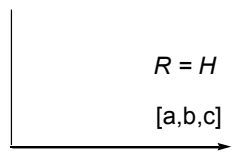<smiles>COC1=NNC(Br)(C(=O)c2ccccc2)c2ccccc21</smiles>

${ }_{30}$ Scheme 9 Deprotonative functionalization of 6-chloro-1,4dimethoxyphthalazine. Reaction conditions: [a] BuLi, THF, $-75{ }^{\circ} \mathrm{C}, 30$ min; [b] Electrophile $\{$ El $\}$ : MeCHO $\{\mathrm{CH}(\mathrm{OH}) \mathrm{Me}\}, \quad \mathrm{PhCHO}$ $\{\mathrm{CH}(\mathrm{OH}) \mathrm{Ph}\}, \mathrm{MeI}\{\mathrm{Me}\}, \mathrm{I}_{2}\{\mathrm{I}\} ;[\mathrm{c}]$ hydrolysis.

\subsection{Metalation of alkoxy- pyridazines and cinnolines}

${ }_{35}$ When subsequently treated with LTMP in THF at $-70{ }^{\circ} \mathrm{C}$ and electrophiles, 3,6-dimethoxypyridazine was converted to the 4-substituted derivatives 7. Good yields were obtained when benzaldehyde, iodomethane, chlorotrimethylsilane and tosyl azide were chosen to trap the lithio intermediate (Scheme $\left.{ }_{40} 10\right) .^{28}$ In contrast, the low conversion observed quenching the reaction mixture with $\mathrm{DCl}$ tends to show that metalation still takes place after the introduction of the electrophiles, by equilibrium shift. ${ }^{13 \mathrm{c}}$ Alternatively, butyllithium can be used to bring about the deprotonation step. ${ }^{29}$

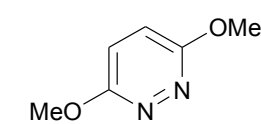

4

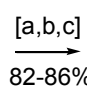

Scheme 10 Deprotonative functionalization of 3,6-dimethoxypyridazine. Reaction conditions: [a] LTMP, THF, $-70{ }^{\circ} \mathrm{C}, 15 \mathrm{~min}$; [b] Electrophile $\{E l\}: \mathrm{PhCHO}\{\mathrm{CH}(\mathrm{OH}) \mathrm{Ph}\}, \mathrm{MeI}\{\mathrm{Me}\}, \mathrm{Me}_{3} \mathrm{SiCl}\left\{\mathrm{SiMe}_{3}\right\}, \mathrm{TsN}_{3}\left\{\mathrm{~N}_{3}\right\}$; [c] hydrolysis.

50 Starting from 3-(methoxyethoxy)pyridazine, only low yields $(12-15 \%)$ of 4 -substituted derivatives were obtained after treatment with LTMP (2 equiv.) in THF at $-70{ }^{\circ} \mathrm{C}$ and subsequent quenching with acetaldehyde or benzaldehyde. ${ }^{23}$

The metalation of 3- and 4-methoxycinnolines was 55 achieved under similar conditions. Starting from 4methoxycinnoline, the 3 -substituted derivatives 8 were obtained in good yields when 2 equiv. of LDA were used. Complications were encountered with 3-methoxycinnoline since both the 4-substituted derivatives 9 and the 4,8${ }_{60}$ disubstituted derivatives were obtained after reaction with 2 equiv. of LTMP followed by trapping with chlorotrimethylsilane (74 and $14 \%$, respectively) or elemental iodine (73 and 22\%) (Scheme 11). ${ }^{19 a}$ 


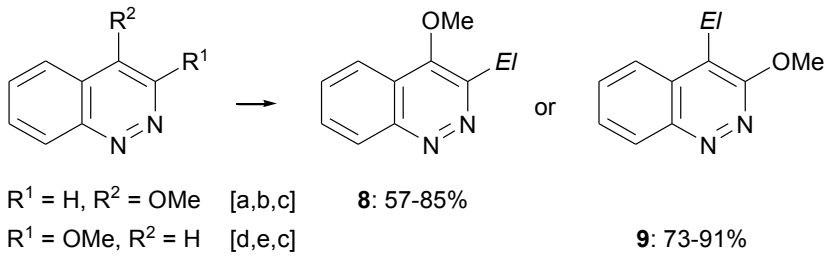

Scheme 11 Deprotonative functionalization of 4- and 3methoxycinnoline. Reaction conditions: [a] LDA, THF, $-75{ }^{\circ} \mathrm{C}, 30 \mathrm{~min}$; [b] Electrophile $\{$ El $\}: \mathrm{PhCHO}\{\mathrm{CH}(\mathrm{OH}) \mathrm{Ph}\}, \mathrm{HCO}_{2} \mathrm{Et}\{\mathrm{CHO}\}, \mathrm{I}_{2}\{\mathrm{I}\} ;[\mathrm{c}]$ 5 hydrolysis; [d] LTMP, THF, $-75{ }^{\circ} \mathrm{C}, 30 \mathrm{~min}$; [e] Electrophile $\{$ El $\}$ : $\mathrm{PhCHO}\{\mathrm{CH}(\mathrm{OH}) \mathrm{Ph}\}, \mathrm{Me}_{3} \mathrm{SiCl}\left\{\mathrm{SiMe}_{3}\right\}, \mathrm{I}_{2}\{\mathrm{I}\}$.

\subsection{Metalation of sulfanyl-, sulfinyl- and sulfonyl- pyridazines and cinnolines}

Studies have been performed in order to compare the ability to 10 direct the metalation of the methoxy group with sulfanyl, sulfinyl and sulfonyl groups. It emerged from the results that the phenylsulfinyl and phenylsulfonyl groups are able to compete with the methoxy group to orient the reaction on the neighboring site using LTMP in THF at $-75^{\circ} \mathrm{C} .{ }^{30}$ Comparable 15 results were obtained with the tert-butylsulfinyl and tertbutylsulfonyl groups. $^{31}$ A sulfonamide group was also compared to a chloro group with the help of a 3,6disubstituted pyridazine, and proved to be the more able to direct the reaction (Scheme 12).<smiles>COc1nnc([SbH2]c2ccccc2)cc1C</smiles><smiles>COc1cc(C)c(Oc2ccccc2)nn1</smiles><smiles>COc1nnc(OP)c(I)c1C</smiles>

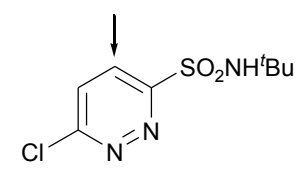

Scheme 12 Regioselectivity of the metalation of 6-sulfur derivatives of 3 methoxy- and 3-chloropyridazine using LTMP in THF at $-75^{\circ} \mathrm{C}$.

Chiral sulfoxides have been used to direct deprotonation reactions of diazines. In the case of 3,6-dimethoxy-4-(425 tolylsulfinyl)pyridazine, metalation using LTMP (3 equiv.) in THF at $-75^{\circ} \mathrm{C}$ followed by trapping with various aldehydes to afford the compounds $\mathbf{1 0}$ proceeded with high diastereoselectivity. ${ }^{32}$ When the tosylimine of benzaldehyde was used as an electrophile, the cyclic sulfenamide $\mathbf{1 1}$ was 30 isolated instead of the expected adduct, probably through 1,2elimination or [2,3] sigmatropic process leading to isobutene and a sulfenic acid, whose amino group attacks the electrophilic sulfenic acid before elimination of water. $^{33}$ (Scheme 13).<smiles>COc1cc([Se][Se])c(OC)nn1</smiles>

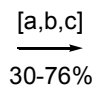

(de $94-99 \%$ )<smiles>CCc1c(OC)nnc(OC)c1[Se]O</smiles><smiles>COc1nnc(OC)c2c1SN([As])[C@H]2c1ccccc1</smiles>

(ee $75 \%)$
Scheme 13 Deprotonative functionalization of 3,6-dimethoxy-4-(4tolylsulfinyl)pyridazine. Reaction conditions: [a] LTMP, THF, $-75^{\circ} \mathrm{C}, 1$ h; [b] Electrophile $\{$ El\}: MeCHO $\{\mathrm{CH}(\mathrm{OH}) \mathrm{Me}\}$, EtCHO $\{\mathrm{CH}(\mathrm{OH}) \mathrm{Et}\}$, $\mathrm{PhCHO}\{\mathrm{CH}(\mathrm{OH}) \mathrm{Ph}\} ;[\mathrm{c}]$ hydrolysis.

40 The sensitivity of the sulfoxide group to nucleophilic addition prevented clean deprotonation reactions from taking place when present at the 4-position of cinnoline. In contrast, 3-tert-butyl- and 3-(4-tolyl)sulfinylcinnoline were metalated with success ( 2 equiv. of base) to furnish the compounds 12 45 13, and a diastereoisomeric excess was observed (Scheme 14). ${ }^{34}$<smiles>[R]C(C)(C)c1cccc2cc([Se][R]#[R])nnc12</smiles>

\section{$[a, b, c]$} [a or d,e,c]<smiles>[R]Oc1nnc2ccccc2c1[Hg]O</smiles>

12: $67-94 \%$ (de $14-99 \%$ ) 13: $56-82 \%$ (de $26 \%$ )
Scheme 14 Deprotonative functionalization of 3-tert-butylsulfinyl- and 3phenylsulfinylcinnoline. Reaction conditions: [a] LTMP, THF, $-75^{\circ} \mathrm{C}, 1$ $50 \mathrm{~h}$; [b] Electrophile $\{$ El\}: $\mathrm{MeCHO}\{\mathrm{CH}(\mathrm{OH}) \mathrm{Me}\}, \mathrm{PhCHO}\{\mathrm{CH}(\mathrm{OH}) \mathrm{Ph}\}$, 4- $\mathrm{MeOC}_{6} \mathrm{H}_{4} \mathrm{CHO}\left\{\mathrm{CH}(\mathrm{OH})\left(4-\mathrm{MeOC}_{6} \mathrm{H}_{4}\right)\right\},{ }^{t} \mathrm{BuCHO}\left\{\mathrm{CH}(\mathrm{OH})^{t} \mathrm{Bu}\right\}, \mathrm{I}_{2}$ $\{\mathrm{I}\}, \mathrm{Bu}_{3} \mathrm{SnCl}\left\{\mathrm{SnBu}_{3}\right\} ;$ [c] hydrolysis; [d] LDA, THF, $-75^{\circ} \mathrm{C}, 30 \mathrm{~min}$; [e] Electrophile $\left\{\right.$ El\}: $\mathrm{DCl}\{\mathrm{D}\}, 4-\mathrm{MeOC}_{6} \mathrm{H}_{4} \mathrm{CHO}\left\{\mathrm{CH}(\mathrm{OH})\left(4-\mathrm{MeOC}_{6} \mathrm{H}_{4}\right)\right\}$.

\subsection{Metalation of $N$-monoprotected aminopyridazines}

55 The metalation of $N$-pivaloyl protected 3-aminopyridazine occurred on treatment with 4 equiv. of LTMP in THF at -70 ${ }^{\circ} \mathrm{C}$, as evidenced by trapping with aldehydes to give the derivatives 14. N-tert-butoxycarbonyl protected 3aminopyridazine was similarly deprotonated; the compound ${ }_{60} \mathbf{1 5}$ was isolated after reaction with aldehydes and subsequent cyclization during the work-up (Scheme 15). ${ }^{23}$<smiles>O=C(O)Nc1cccnn1</smiles>

$\mathrm{R}={ }^{t} \mathrm{Bu}, \mathrm{O}^{t} \mathrm{Bu}$

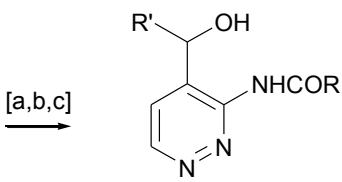

14: $52-62 \%$<smiles>[R]C1OC(=O)Nc2nnccc21</smiles>

15: $36-37 \%$
Scheme 15 Deprotonative functionalization of $\mathrm{N}$-pivaloyl and $\mathrm{N}$-tertbutoxycarbonyl protected 3-aminopyridazine. Reaction conditions: [a] 65 LTMP, THF, $-70{ }^{\circ} \mathrm{C}$; [b] Electrophile $\left\{R^{\prime}\right\}$ : MeCHO $\{\mathrm{Me}\}, \mathrm{PhCHO}$ $\{\mathrm{Ph}\} ;$ [c] hydrolysis. 
With $N$-pivaloyl and $N$-tert-butoxycarbonyl protected 4 aminopyridazine, reaction with LTMP in THF at $-70{ }^{\circ} \mathrm{C}$ exclusively occurred at the 5-position. This was evidenced by further transformation of the lithio intermediates to afford the 5 compounds 16 and $\mathbf{1 7}$, respectively (Scheme 16). ${ }^{35}$<smiles>[R]C(=O)Nc1ccnnc1</smiles>

$\mathrm{R}={ }^{t} \mathrm{Bu}, \mathrm{O}^{t} \mathrm{Bu}$<smiles>[R]C(O)c1cnncc1NC(=O)CC(C)C</smiles>

16: $43-63 \%$<smiles>[R]C(O)c1cnncc1NC(=O)OCC</smiles>

17: $23-25 \%$

Scheme 16 Deprotonative functionalization of $N$-pivaloyl and $N$-tertbutoxycarbonyl protected 4-aminopyridazine. Reaction conditions: [a] LTMP, THF, $-70{ }^{\circ} \mathrm{C}, 2.5 \mathrm{~h}$; [b] Electrophile $\left\{R^{\prime}\right\}: \operatorname{MeCHO}\{\mathrm{Me}\}$, ${ }_{10} \mathrm{PhCHO}\{\mathrm{Ph}\} ;[\mathrm{c}]$ hydrolysis.

\subsection{Metalation of pyridazinecarboxamides and pyridazinethiocarboxamides}

Lithiation of $N$-(tert-butyl)pyridazine-4-carboxamide using LTMP in THF at low temperature occurred regioselectively at 15 the 5-position, leading to the compounds $\mathbf{1 8}$ (Scheme 17). In contrast, mixtures of 5- and 6-substituted derivatives were obtained starting from $N$-benzylpyridazine-4-carboxamide. ${ }^{35}$<smiles>CC(C)CNC(=O)c1ccnnc1</smiles>

$\underset{41-79 \%}{\stackrel{[a, b, c]}{\longrightarrow}}$

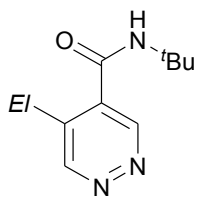

18
Scheme 17 Deprotonative functionalization of $N$-(tert-butyl)pyridazine-420 carboxamide. Reaction conditions: [a] LTMP, THF, $-75{ }^{\circ} \mathrm{C}, 15 \mathrm{~min}$ to 2 h; [b] Electrophile $\{$ El\}: $\mathrm{MeCHO}\{\mathrm{CH}(\mathrm{OH}) \mathrm{Me}\}, \mathrm{PhCHO}\{\mathrm{CH}(\mathrm{OH}) \mathrm{Ph}\}$, $\mathrm{Me}_{3} \mathrm{SiCl}\left\{\mathrm{SiMe}_{3}\right\} ;[\mathrm{c}]$ hydrolysis.

Reaction of $N$-(tert-butyl)pyridazine-3-carboxamide was reported later under similar conditions. Deprotonation 25 generally led to the 4-substituted derivatives $\mathbf{1 9}$, except with elemental iodine for which a halogen migration occurred (compound 20), probably promoted by the excess of base (4 equiv. were used) during the trapping step. Turning to the corresponding thiocarboxamide modified the regioselectivity 30 in favor of the 5-position. This opened an entry to the 5substituted derivatives $\mathbf{2 1}$ though in moderate yields, probably in relation with the absence of stabilization of the lithio derivative by chelation (Scheme 18). It was noted that when a methylsulfanyl group was located at the 6-position of $\mathrm{N}$-(tert-

35 butyl)pyridazine-3-carboxamide, reaction took place in its vicinity using LDA. $^{36}$

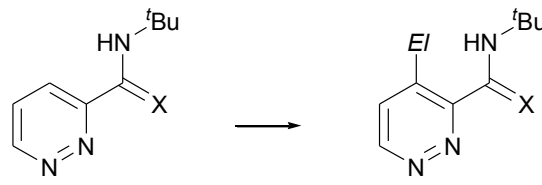

$\mathrm{X}=\mathrm{O}$

$X=S$
19: $89-96 \%$ $[a, b, c]$

$[a, d, c]$<smiles></smiles>

$20(E l=1): 65 \%$

21: $14-63 \%$
Scheme 18 Deprotonative functionalization of $N$-(tert-butyl)pyridazine-3carboxamide. Reaction conditions: [a] LTMP, THF, $-75{ }^{\circ} \mathrm{C}, 1 \mathrm{~h}$; [b] 40 Electrophile $\{$ El $\}: \mathrm{MeCHO}\{\mathrm{CH}(\mathrm{OH}) \mathrm{Me}\}, \mathrm{PhCHO}\{\mathrm{CH}(\mathrm{OH}) \mathrm{Ph}\}, \mathrm{I}_{2}\{\mathrm{I}\}$; [c] hydrolysis; [d] Electrophile $\{E l\}$ : $\mathrm{MeCHO}\{\mathrm{CH}(\mathrm{OH}) \mathrm{Me}\}, \mathrm{PhCHO}$ $\{\mathrm{CH}(\mathrm{OH}) \mathrm{Ph}\}, \mathrm{Ph}_{2} \mathrm{CO}\left\{\mathrm{C}(\mathrm{OH}) \mathrm{Ph}_{2}\right\}, \mathrm{Bu}_{3} \mathrm{SnCl}\left\{\mathrm{SnBu}_{3}\right\}, \mathrm{MeI}\{\mathrm{Me}\}, \mathrm{I}_{2}\{\mathrm{I}\}$, $\mathrm{C}_{2} \mathrm{Cl}_{6}\{\mathrm{Cl}\}$.

\section{Metalation of pyrimidines and quinazolines}

\section{${ }_{45}$ 3.1 Metalation of bare pyrimidine and long range activated pyrimidines and quinazolines}

Alkyldiazines are in general prone to lateral metalation. 5Methylpyrimidine is an exception since it was deprotonated at the 4-position on treatment with LDA, a result evidenced by 50 trapping with benzophenone. ${ }^{14}$ This is the first pyrimidine metalation.

The reaction of bare pyrimidine with LTMP is not very tempting under a synthesis point of view. When attempted at various temperatures in THF or DEE, only small amounts of 55 substrate and 4,4'-dimer $\mathbf{2 2}$ were identified, due to the instability of the lithio compound under the conditions applied. The compatibility of hindered lithium amides with some electrophiles allowed the in situ quenching of the 4lithio compound to furnish the derivatives $\mathbf{2 3}$ though the 4,660 disubstituted product $\mathbf{2 4}$ was produced together using benzophenone (Scheme 19). ${ }^{17}$<smiles>c1cc(-c2ccncn2)ncn1</smiles>

22<smiles>c1cncnc1</smiles>
$\underset{16-54 \%}{\stackrel{[a, b]}{\longrightarrow}}$<smiles>ClCc1ccncn1</smiles>

23<smiles>OC(c1ccccc1)(c1ccccc1)c1cc(C(O)(c2ccccc2)c2ccccc2)ncn1</smiles>

Scheme 19 Deprotonative functionalization of pyrimidine using the in situ trapping technique. Reaction conditions: [a] LTMP, THF, $-70{ }^{\circ} \mathrm{C}$, ${ }_{65}$ Electrophile $\{E l\}: \mathrm{Me}_{3} \mathrm{SiCl}\left\{\mathrm{SiMe}_{3}\right\}, \mathrm{PhCHO}\{\mathrm{CH}(\mathrm{OH}) \mathrm{Ph}\}, \mathrm{Ph}_{2} \mathrm{CO}$ $\left\{\mathrm{C}(\mathrm{OH}) \mathrm{Ph}_{2}\right\} ;[\mathrm{b}]$ hydrolysis.

Combining LTMP (1.5 equiv.) with $\mathrm{ZnCl}_{2} \cdot$ TMEDA (0.5 equiv.) in THF at $25{ }^{\circ} \mathrm{C}$, the 4-metalated compound could be accumulated to give, after trapping, the products $\mathbf{2 5}$ (Scheme $7020) .^{18}$<smiles>c1cncnc1</smiles>
$\underset{42-57 \%}{\stackrel{[a, b]}{\longrightarrow}}$<smiles>Clc1ccncn1</smiles> 
Scheme 20 Deprotonative functionalization of pyrimidine using a mixed Li/Zn amide. Reaction conditions: [a] $\mathrm{ZnCl}_{2}$.TMEDA, LTMP, THF, 25 ${ }^{\circ} \mathrm{C}, 2 \mathrm{~h}$; [b] Electrophile $\{$ El $\}: \mathrm{I}_{2}\{\mathrm{I}\}, \mathrm{ClPPh}_{2}\left\{\mathrm{PPh}_{2}\right\}$.

With a methoxy group located at the 2-position, the 4-lithio 5 derivative could be accumulated using 4 equiv. of LTMP (albeit a short reaction time has to be used) owing to an increase of the acidity of the hydrogens and a stabilization by electron-withdrawing effect. The 4-functionalized derivatives 26 were isolated in moderate yields after trapping with "hard" 10 electrophiles such as deuterium chloride (56\%), benzaldehyde (29\%), acetaldehyde (26\%) or 2,3,4-trimethoxybenzaldehyde $(28 \%)$. Using electrophiles more compatible with lithium amides, the formation of 4,6-disubstituted pyrimidines 27 (41\% using chlorotrimethylsilane and $25 \%$ using phenyl 15 disulfide) and even 4,5,6-trisubstituted pyrimidines 28 (7\% using elemental iodine) could not be avoided (Scheme 21). Similar results have been observed starting from 2-(4methoxyphenyl)pyrimidine. ${ }^{17}$<smiles>[R]c1ncccn1</smiles><smiles>[R]c1nccc(Cl)n1</smiles>

$\mathrm{R}=\mathrm{OMe}$
26<smiles>[R]c1nc([CH])cc([NH2+])n1</smiles>

27<smiles>[R]c1nc([Z])c([CH])c([CH])n1</smiles>

28
20 Scheme 21 Deprotonative functionalization of 2-methoxypyrimidine. Reaction conditions: [a] LTMP, THF, $-75{ }^{\circ} \mathrm{C}, 5 \mathrm{~min}$; [b] Electrophile $\{E l\}: \mathrm{DCl}\{\mathrm{D}\}, \mathrm{PhCHO}\{\mathrm{CH}(\mathrm{OH}) \mathrm{Ph}\}, \mathrm{MeCHO}\{\mathrm{CH}(\mathrm{OH}) \mathrm{Me}\}, 2,3,4-$ $\operatorname{tri}(\mathrm{MeO}) \mathrm{C}_{6} \mathrm{H}_{2} \mathrm{CHO}\left\{\mathrm{CH}(\mathrm{OH})\left(2,3,4-\operatorname{tri}(\mathrm{MeO}) \mathrm{C}_{6} \mathrm{H}_{2}\right)\right\}, \mathrm{Me}_{3} \mathrm{SiCl}\left\{\mathrm{SiMe}_{3}\right\}$, $(\mathrm{PhS})_{2}\{\mathrm{SPh}\}, \mathrm{I}_{2}\{\mathrm{I}\} ;[\mathrm{c}]$ hydrolysis.

25 With a chloro group located at the 2-position, the accumulation of a 4-metalated derivative proved not satisfactory using LTMP. ${ }^{17}$ Nevertheless, using the mixed $\mathrm{Mg} / \mathrm{Li}$ amide TMPMgCl$\cdot \mathrm{LiCl}$ (1 equiv.), it became possible when used in THF at temperatures between $30-55$ and $-40{ }^{\circ} \mathrm{C}$, as demonstrated by interception with electrophiles to furnish the 4-functionalized derivatives 29 (Scheme 22). ${ }^{37}$<smiles>Clc1ncccn1</smiles>

$[a, b, c]$

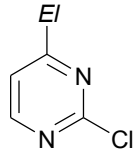

29
Scheme 22 Deprotonative functionalization of 2-chloropyrimidine. 35 Reaction conditions: [a] TMPMgCl$\cdot \mathrm{LiCl}, \mathrm{THF},-55$ to $-40{ }^{\circ} \mathrm{C}, 2 \mathrm{~h}$; [b] Electrophile \{El\}: $\mathrm{MeSSO}_{2} \mathrm{Me}\{\mathrm{SMe}\}, 4-\mathrm{BrC}_{6} \mathrm{H}_{4} \mathrm{CHO}\{\mathrm{CH}(\mathrm{OH})(4-$ $\left.\left.\mathrm{BrC}_{6} \mathrm{H}_{4}\right)\right\}$; [c] hydrolysis.

Owing to the substituent at the 2-position, which avoids a nucleophilic attack of the base at this position, 2-tert-butyl${ }_{40} 4(3 H)$-quinazolinone was lithiated on the benzene moiety upon treatment with TMEDA-chelated sec-butyllithium (4 equiv.) at $-20{ }^{\circ} \mathrm{C}$, regioselectively leading to the 5-substituted derivatives 30 (Scheme 23). ${ }^{38}$ 5-Aryl derivatives were then prepared by coupling from compounds $\mathbf{3 0}\left(E l=\mathrm{B}(\mathrm{OH})_{2}\right)$.<smiles>CC(C)(C)c1nc2ccccc2c(=O)[nH]1</smiles>

$\underset{17-94 \%}{\stackrel{[a, b, c]}{\longrightarrow}}$ 45

Scheme 23 Deprotonative functionalization of 2-tert-butyl-4(3H)quinazolinone. Reaction conditions: [a] ${ }^{s} \mathrm{BuLi}$, TMEDA, THF, $-20{ }^{\circ} \mathrm{C}, 1$ h; [b] Electrophile $\{$ El $\}$ : MeCHO $\{\mathrm{CH}(\mathrm{OH}) \mathrm{Me}\}, \mathrm{PhCHO}\{\mathrm{CH}(\mathrm{OH}) \mathrm{Ph}\}$, $(\mathrm{PhS})_{2}\{\mathrm{SPh}\}, \mathrm{Bu}_{3} \mathrm{SnCl}\left\{\mathrm{SnBu}_{3}\right\}, \mathrm{I}_{2} \quad\{\mathrm{I}\}, \mathrm{B}(\mathrm{OMe})_{3} \quad\left\{\mathrm{~B}(\mathrm{OH})_{2}\right\} ; \quad[\mathrm{c}]$ 50 hydrolysis.

\subsection{Metalation of halopyrimidines}

In the bromodiazine series, the success of the metalation depends closely on the reaction conditions. When a mixture of 5-bromopyrimidine and a carbonyl compound was treated by 55 LDA ( 1 equiv.) in DEE at $-100{ }^{\circ} \mathrm{C}$ for $2 \mathrm{~h}$, the 4 -substituted 5-bromopyrimidines $\mathbf{3 1}$ were obtained after hydrolysis in moderate yields. In the absence of electrophile, the dihydropyrimidylpyrimidine $\mathbf{3 2}$ was isolated after hydrolysis in $32 \%$ yield (Scheme 24). ${ }^{39}$ Accumulation of a 4-metalated 5${ }_{60}$ bromopyrimidine proved possible using the mixed $\mathrm{Mg} / \mathrm{Li}$ amide $\mathrm{TMPMgCl} \cdot \mathrm{LiCl}$ in $\mathrm{THF}$ at temperatures between -55 and $-40{ }^{\circ} \mathrm{C}$. $^{37}$<smiles>Clc1ncncc1Br</smiles>

Scheme 24 Deprotonative functionalization of 5-bromopyrimidine using 65 the in situ trapping technique. Reaction conditions: [a] LDA, DEE, -100 ${ }^{\circ} \mathrm{C}$, Electrophile $\{$ El $\}$ : $\quad 4-\mathrm{FC}_{6} \mathrm{H}_{4} \mathrm{C}(\mathrm{O})\left(2-\mathrm{ClC}_{6} \mathrm{H}_{4}\right) \quad\left\{\mathrm{COH}\left(4-\mathrm{FC}_{6} \mathrm{H}_{4}\right)(2-\right.$ $\left.\left.\mathrm{ClC}_{6} \mathrm{H}_{4}\right)\right\}$, 4- $\left.\mathrm{ClC}_{6} \mathrm{H}_{4} \mathrm{C}(\mathrm{O})\right)^{\mathrm{i}} \mathrm{Pr} \quad\left\{\mathrm{COH}\left(4-\mathrm{ClC}_{6} \mathrm{H}_{4}\right)\left({ }^{\mathrm{i}} \mathrm{Pr}\right)\right\}, \quad \mathrm{PhCHO}$ $\{\mathrm{CH}(\mathrm{OH}) \mathrm{Ph}\} ;[\mathrm{b}]$ hydrolysis.

Starting from 2,4-dibromopyrimidine, lithio compounds 70 could be accumulated at $-100{ }^{\circ} \mathrm{C}$ using 3 equiv. of LDA or more hindered and basic LTMP. The 5-lithio derivative was mainly generated using the former and the 6-lithio using the latter. This was shown by interception with acetaldehyde or 4 methoxybenzaldehyde (20-26\% of $\mathbf{3 3}$ and $2-5 \%$ of $\mathbf{3 4}$ using 75 LDA, and $21-24 \%$ of $\mathbf{3 4}$ and $0-8 \%$ of $\mathbf{3 3}$ using LTMP) (Scheme 25). ${ }^{20}$<smiles>Brc1ccnc(Br)n1</smiles><smiles>[R]C(O)c1cnc(Br)nc1Br</smiles><smiles>[R]C(O)c1cc(Br)nc(Br)n1</smiles>

Scheme 25 Deprotonative functionalization of 2,4-dibromopyrimidine Reaction conditions: [a] LDA or LTMP, THF, $-100{ }^{\circ} \mathrm{C}, 30 \mathrm{~min}$; [b] 80 Electrophile $\{R\}$ : MeCHO $\{\mathrm{Me}\}, \quad 4-\mathrm{MeOC}_{6} \mathrm{H}_{4} \mathrm{CHO} \quad\{\mathrm{CH}(\mathrm{OH})(4-$ $\left.\left.\mathrm{MeOC}_{6} \mathrm{H}_{4}\right)\right\}$; [c] hydrolysis.

When the corresponding dichloropyrimidine was treated with LTMP, the regioselectivity of the reaction proved to be 
dependent on the reaction conditions. 1:1 Mixtures of 5- and 6-substituted derivatives were obtained when the substrate was successively treated with LTMP in THF at $-70{ }^{\circ} \mathrm{C}$ and an electrophile. The 5-lithio compound was generated in a THF5 DEE mixture at $-100{ }^{\circ} \mathrm{C}$ whereas the 6 -lithio was formed in a THF-HMPA mixture at $-70{ }^{\circ} \mathrm{C}$; trapping with acetaldehyde afforded the corresponding alcohols $\mathbf{3 5}$ and $\mathbf{3 6}$ in 11 and $18 \%$ yield, respectively (Scheme 26). ${ }^{21}$

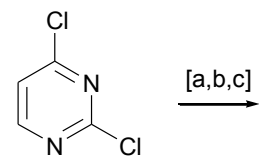<smiles>[R]C(O)c1cnc(Cl)nc1Cl</smiles><smiles>[R]C(O)c1cc(Cl)nc(Cl)n1</smiles>

${ }_{10}$ Scheme 26 Deprotonative functionalization of 2,4-dichloropyrimidine. Reaction conditions: [a] LTMP; [b] Electrophile: MeCHO; [c] hydrolysis.

Using LDA in THF at $-80{ }^{\circ} \mathrm{C}$ resulted in the regioselective formation of the 5-lithio derivative, as demonstrating by trapping with benzaldehyde or chlorotrimethylsilane to 15 furnish the compounds $\mathbf{3 7}$ in low yields. The derivatives $\mathbf{3 8}$ and 39 were analogously accessed from the 5-lithio compounds of 4,6-dichloro- and 2,4,6-trichloropyrimidine, benefiting from doubly activated positions (Scheme 27). Butyllithium could also be used for the deprotonation of 4,620 dichloro- and 2,4,6-trichloropyrimidine, but the expected alcohols were given in lower yields after trapping with benzaldehydes. $^{40}$<smiles>[R]c1cc([R])nc([R])n1</smiles>

$\mathrm{R}^{1}=\mathrm{R}^{3}=\mathrm{Cl} ; \mathrm{R}^{2}=\mathrm{H}$

$\mathrm{R}^{1}=\mathrm{H} ; \mathrm{R}^{2}=\mathrm{R}^{3}=\mathrm{Cl}$

$\mathrm{R}^{1}=\mathrm{R}^{2}=\mathrm{R}^{3}=\mathrm{Cl}$ $\stackrel{[a, b, c]}{\longrightarrow}$<smiles>[R]c1nc([R])c([CH])c([R])n1</smiles>

38: $44-60 \%$

39: $67-84 \%$
37: $6-38 \%$

Scheme 27 Deprotonative functionalization of 2,4-dichloro-, 4,625 dichloro- and 2,4,6-trichloropyrimidine. Reaction conditions: [a] LDA, THF, $-80{ }^{\circ} \mathrm{C}, 30 \mathrm{~min}$; [b] Electrophile $\{$ El\}: PhCHO $\{\mathrm{CH}(\mathrm{OH}) \mathrm{Ph}\}$, $\mathrm{Me}_{3} \mathrm{SiCl}\left\{\mathrm{SiMe}_{3}\right\} ;[\mathrm{c}]$ hydrolysis.

A similar problem of regioselectivity arose in the case of 2,4-dichloropyrimidine and 2-(methylsulfanyl)-430 chloropyrimidine. Whereas LDA in THF at $-70{ }^{\circ} \mathrm{C}$ mainly metalated both substrates at the 5-position next to the chloro group (9:1 and 19:1 ratio, respectively, when aldehydes were used to trap the lithio intermediates), LTMP concomitantly attacked the hydrogen next to the ring nitrogen (1:1 and 1:2 35 ratio, respectively). Surprisingly, when elemental iodine was used to trap the mixture of lithio compounds generated with LDA or LTMP from 2-(methylsulfanyl)-4-chloropyrimidine, only the 6-iodo derivative was obtained; this result could be due to a quick TMP-promoted isomerization of the 5-iodo 40 derivative during the trapping step. ${ }^{41}$ Conversion of the 6-iodo derivative to 6-aryl-4-chloro-2-(methylsulfanyl)pyrimidine-5carbonitriles endowed with antileshmanial activities, was performed using cross-coupling with phenylboronic acid or 3- anisylzinc chloride, and subsequent lithiation at the 5 position 45 as key steps.

4-Chloro-2,6-dimethoxypyrimidine was converted into the 5-lithio derivative using either LTMP to give the compounds $\mathbf{4 0}^{42}$ or butyllithium to afford the compound $41 .^{25 b, 43}$ Better yields were obtained using the former (Scheme 28).

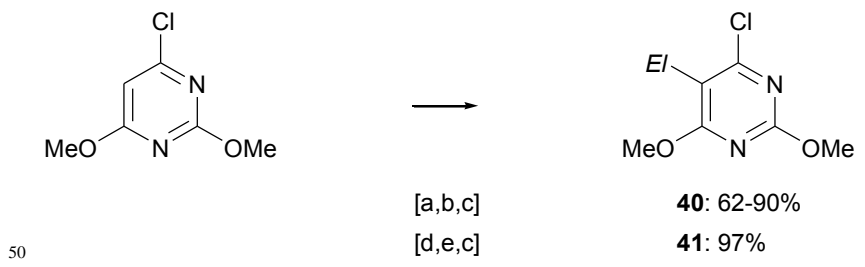

Scheme 28 Deprotonative functionalization of 4-chloro-2,6dimethoxypyrimidine. Reaction conditions: [a] LTMP, THF, $-25^{\circ} \mathrm{C}, 1 \mathrm{~h}$; [b] Electrophile $\{E l\}$ : DCl/EtOD $\{\mathrm{D}\}, \mathrm{MeCHO}\{\mathrm{CH}(\mathrm{OH}) \mathrm{Me}\}, \mathrm{PhCHO}$ $\{\mathrm{CH}(\mathrm{OH}) \mathrm{Ph}\}, \quad 2-\mathrm{MeOC}_{6} \mathrm{H}_{4} \mathrm{CHO} \quad\left\{\mathrm{CH}(\mathrm{OH})\left(2-\mathrm{MeOC}_{6} \mathrm{H}_{4}\right)\right\}, \quad 3,4,5-$ $55 \operatorname{tri}(\mathrm{MeO}) \mathrm{C}_{6} \mathrm{H}_{2} \mathrm{CHO}\left\{\mathrm{CH}(\mathrm{OH})\left(3,4,5-\operatorname{tri}(\mathrm{MeO}) \mathrm{C}_{6} \mathrm{H}_{2}\right)\right\}, \mathrm{HCO}_{2} \mathrm{Et}\{\mathrm{CHO}\}, \mathrm{I}_{2}$ $\{\mathrm{I}\}, \mathrm{Me}_{3} \mathrm{SnCl}\left\{\mathrm{SnMe}_{3}\right\} ;$ [c] hydrolysis; [d] BuLi, THF, $-75^{\circ} \mathrm{C}, 10 \mathrm{~min}$; [e] Electrophile $\left\{\right.$ El\}: $\mathrm{TsN}_{3}\left\{\mathrm{~N}_{3}\right\}$.

2,4-Difluoro- and 4-fluoro-2-(methylsulfanyl)pyrimidine regioselectively underwent $\mathrm{LDA}$-promoted metalation at the ${ }_{60} 5$-position in THF at $-75{ }^{\circ} \mathrm{C}$ to give the trisubstituted compounds 42 after electrophilic trapping (Scheme 29). ${ }^{44}$ Halogenated and dihalogenated 2- or 4(trifluoromethyl)pyrimidine were similarly amenable to deprotonation at the 5-position using LDA in THF at -75 ${ }_{65}^{\circ} \mathrm{C} .{ }^{15}$<smiles>[R]c1nccc(F)n1</smiles>

$\underset{27-87 \%}{\stackrel{[a, b, c]}{\longrightarrow}}$

$\mathrm{R}=\mathrm{F}, \mathrm{SMe}$

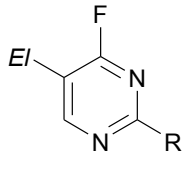

42
Scheme 29 Deprotonative functionalization of 2,4-difluoro- and 4-fluoro2-(methylsulfanyl)pyrimidine. Reaction conditions: [a] LDA, THF, -75 ${ }^{\circ} \mathrm{C}, 30 \mathrm{~min}$; [b] Electrophile $\{$ El $\}$ : $\mathrm{MeCHO}\{\mathrm{CH}(\mathrm{OH}) \mathrm{Me}\}, \mathrm{PhCHO}$ $70\{\mathrm{CH}(\mathrm{OH}) \mathrm{Ph}\}, \quad 2-\mathrm{MeOC}_{6} \mathrm{H}_{4} \mathrm{CHO} \quad\left\{\mathrm{CH}(\mathrm{OH})\left(2-\mathrm{MeOC}_{6} \mathrm{H}_{4}\right)\right\}, \quad 2,4-$ $\operatorname{diClC}_{6} \mathrm{H}_{3} \mathrm{CHO} \quad\left\{\mathrm{CH}(\mathrm{OH})\left(2,4-\mathrm{diClC}_{6} \mathrm{H}_{3}\right)\right\}, \quad 3,4,5$-tri $(\mathrm{MeO}) \mathrm{C}_{6} \mathrm{H}_{2} \mathrm{CHO}$ $\left\{\mathrm{CH}(\mathrm{OH})\left(3,4,5-\operatorname{tri}(\mathrm{MeO}) \mathrm{C}_{6} \mathrm{H}_{2}\right)\right\}, \mathrm{I}_{2}\{\mathrm{I}\}, \mathrm{HCO}_{2} \mathrm{Et}\{\mathrm{CHO}\}, \mathrm{CO}_{2}\left\{\mathrm{CO}_{2} \mathrm{H}\right\}$; [c] hydrolysis.

Conversely, LTMP in THF at $-100{ }^{\circ} \mathrm{C}$ was found to 75 deprotonate 2-(methylsulfanyl)-4-trifluoromethylpyrimidine regioselectively next to nitrogen, leading to the 6-substituted derivatives $\mathbf{4 3}$. The 4,4'-dimer 44 ranked among the most abundant by-products. ${ }^{45}$ 4-Iodo-2-(methylsulfanyl)pyrimidine behaved similarly. It was converted to the 6-lithio derivative 80 when treated with a very hindered base in THF at $-100{ }^{\circ} \mathrm{C}$ for 10 min, affording the compounds $\mathbf{4 5}^{46}$ (Scheme 30 ). 


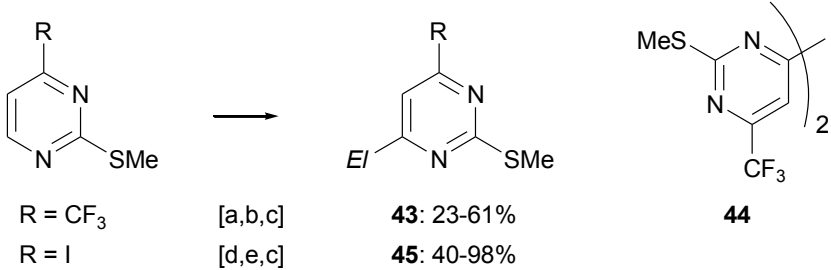

Scheme 30 Deprotonative functionalization of 2-(methylsulfanyl)-4trifluoromethyl- and 2-(methylsulfanyl)-4-iodopyrimidine. Reaction conditions: [a] LTMP, THF, $-100{ }^{\circ} \mathrm{C}, 1 \mathrm{~h}$; [b] Electrophile $\{$ El $\}$ : MeCHO

$5\{\mathrm{CH}(\mathrm{OH}) \mathrm{Me}\}, \mathrm{PhCHO}\{\mathrm{CH}(\mathrm{OH}) \mathrm{Ph}\}, 2-\mathrm{MeOC}_{6} \mathrm{H}_{4} \mathrm{CHO}\{\mathrm{CH}(\mathrm{OH})(2-$ $\left.\left.\mathrm{MeOC}_{6} \mathrm{H}_{4}\right)\right\}, \quad 2,4-\mathrm{diClC}_{6} \mathrm{H}_{3} \mathrm{CHO} \quad\left\{\mathrm{CH}(\mathrm{OH})\left(2,4-\operatorname{diClC}_{6} \mathrm{H}_{3}\right)\right\}, \quad 3,4,5-$ $\operatorname{tri}(\mathrm{MeO}) \mathrm{C}_{6} \mathrm{H}_{2} \mathrm{CHO} \quad\left\{\mathrm{CH}(\mathrm{OH})\left(3,4,5-\operatorname{tri}(\mathrm{MeO}) \mathrm{C}_{6} \mathrm{H}_{2}\right)\right\}, \quad \mathrm{I}_{2} \quad\{\mathrm{I}\}, \quad \mathrm{HCO}_{2} \mathrm{Et}$ $\{\mathrm{CHO}\}, \mathrm{CO}_{2}\left\{\mathrm{CO}_{2} \mathrm{H}\right\} ;$ [c] hydrolysis; [d] lithium $\mathrm{N}$-tert-butyl- $\mathrm{N}-(1-$ isopropylpentyl)amide, THF, $-100{ }^{\circ} \mathrm{C}, 10 \mathrm{~min}$; [e] Electrophile $\{$ El\}: ${ }_{10} \mathrm{MeCHO}\{\mathrm{CH}(\mathrm{OH}) \mathrm{Me}\}, \mathrm{PhCHO}\{\mathrm{CH}(\mathrm{OH}) \mathrm{Ph}\}, \mathrm{Ph}_{2} \mathrm{CO}\left\{\mathrm{C}(\mathrm{OH}) \mathrm{Ph}_{2}\right\}$, MeI $\{\mathrm{Me}\}, \mathrm{EtI}\{\mathrm{Et}\}, \mathrm{Me}_{3} \mathrm{SiCl}\left\{\mathrm{SiMe}_{3}\right\}, \mathrm{HCO}_{2} \mathrm{Et}\{\mathrm{CHO}\}, \mathrm{I}_{2}\{\mathrm{I}\}$.

\subsection{Metalation of alkoxy- pyrimidines and quinazolines}

Unlike 2,4-dihalopyrimidines, 2,4-dimethoxypyrimidine was regioselectively metalated at the methoxy-adjacent position 15 when treated with LTMP in DEE at $0{ }^{\circ} \mathrm{C}$. This was shown by trapping the lithio compounds with aldehydes, carbon dioxide, dimethylformamide, ethyl chloroformiate or chlorotrimethylsilane in yields ranging from 4 to $65 \% .{ }^{47}$ These deprotonation conditions were also applied to functionalize a 20 series of pyrimidines including $\mathrm{N}$-pivaloyl protected 4aminopyrimidine (chlorotrimethylsilane quench) in low yields.

5-Methoxy, 2,4-dimethoxy (or 2,4-dibenzyloxy), 4,6dimethoxy and 2,4,6-trimethoxypyrimidine were all lithiated 25 next to the methoxy (or benzyloxy) group using LTMP in THF at $-78{ }^{\circ} \mathrm{C}$ for $15 \mathrm{~min}$, leading to substituted derivatives 46-48 in medium to high yields, depending on the ability of the electrophile to coexist with the base long enough to allow equilibrium shift of the deprotonation reaction (Scheme $3031)^{25 b, 28}$<smiles>COc1cncnc1</smiles>
$\underset{47-49 \%}{\stackrel{[a, b, c]}{\longrightarrow}}$<smiles>COc1ccnc(OC)n1</smiles>
$\underset{68-98 \%}{\stackrel{[a, b, c]}{\longrightarrow}}$<smiles>[R]c1nc(OC)cc(OC)n1</smiles>
$\underset{75-99 \%}{\stackrel{[a, b, d]}{\longrightarrow}}$

$\mathrm{R}=\mathrm{H}, \mathrm{OMe}$

Scheme 31 Deprotonative functionalization of 5-methoxy-, 2,4dimethoxy-, 4,6-dimethoxy- and 2,4,6-trimethoxypyrimidine. Reaction conditions: [a] LTMP, THF, $-78{ }^{\circ} \mathrm{C}, 15 \mathrm{~min}$; [b] Electrophile \{El\}: ${ }_{35} \mathrm{PhCHO}\{\mathrm{CH}(\mathrm{OH}) \mathrm{Ph}\}, \mathrm{MeI}\{\mathrm{Me}\}, \mathrm{Me}_{3} \mathrm{SiCl}\left\{\mathrm{SiMe}_{3}\right\} ;$ [c] hydrolysis; [d]
Electrophile $\left\{\right.$ El\}: $\mathrm{PhCHO}\{\mathrm{CH}(\mathrm{OH}) \mathrm{Ph}\}, \mathrm{MeI}\{\mathrm{Me}\}, \mathrm{Me}_{3} \mathrm{SiCl}\left\{\mathrm{SiMe}_{3}\right\}$, $\mathrm{PhCOCl}\{\mathrm{COPh}\}$.

Similar results were obtained starting from 2-chloro-4methoxypyrimidine, allowing the synthesis of the 540 substituted derivatives 49. Trapping with elemental iodine only furnished the expected 5-iodo derivative $\mathbf{5 0}$ when the reaction was performed at $-100{ }^{\circ} \mathrm{C}$. At $-75{ }^{\circ} \mathrm{C}, 2$-chloro-6iodo-4-methoxypyrimidine $\mathbf{5 1}$ was formed instead, as previously noted with 2-(methylsulfanyl)-4-chloropyrimidine 45 (Scheme 32). ${ }^{48}$<smiles>COc1ccnc(Cl)n1</smiles><smiles>C=C</smiles>

$[a, b, c]$ $[\mathrm{d}, \mathrm{e}]$ $[\mathrm{a}, \mathrm{e}]$<smiles>CCc1cnc(Cl)nc1OC</smiles><smiles>COc1nc(Cl)ncc1I</smiles><smiles>COc1cc([Tl])nc(C)n1</smiles>

49: $30-85 \%$

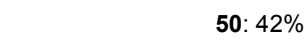

$50: 42 \%$
Scheme 32 Deprotonative functionalization of 2-chloro-4methoxypyrimidine. Reaction conditions: [a] LTMP, THF, $-70{ }^{\circ} \mathrm{C}, 1 \mathrm{~h}$; [b] Electrophile $\{$ El\}: DCl/EtOD $\{\mathrm{D}\}, \mathrm{MeCHO}\{\mathrm{CH}(\mathrm{OH}) \mathrm{Me}\}, \mathrm{PhCHO}$ $50\{\mathrm{CH}(\mathrm{OH}) \mathrm{Ph}\}, \quad 2-\mathrm{MeOC}_{6} \mathrm{H}_{4} \mathrm{CHO} \quad\left\{\mathrm{CH}(\mathrm{OH})\left(2-\mathrm{MeOC}_{6} \mathrm{H}_{4}\right)\right\}, \quad 3,4,5-$ $\operatorname{tri}(\mathrm{MeO}) \mathrm{C}_{6} \mathrm{H}_{2} \mathrm{CHO}\left\{\mathrm{CH}(\mathrm{OH})\left(3,4,5-\operatorname{tri}(\mathrm{MeO}) \mathrm{C}_{6} \mathrm{H}_{2}\right)\right\}, \mathrm{Me}_{3} \mathrm{SiCl}\left\{\mathrm{SiMe}_{3}\right\}$, $\mathrm{HCO}_{2} \mathrm{Et}\{\mathrm{CHO}\}$; [c] hydrolysis; [d] LTMP, THF, $-100{ }^{\circ} \mathrm{C}, 1 \mathrm{~h}$; [e] $\mathrm{I}_{2}$.

Metalation of the benzene ring of 4-substituted quinazoline was more easily observed when substituents can orient the 55 deprotonation. Thus, metalation of 4-anilino- ${ }^{27}$ 4-(4methoxyphenyl)-, ${ }^{19 \mathrm{~b}}$ and 4-(4-trifluoromethylphenyl)-6,7dimethoxyquinazoline ${ }^{19 b}$ using 4-5 equiv. of lithium amide in THF at $-75{ }^{\circ} \mathrm{C}$ affected the 8 -position. A similar result was noted when 6,7-dimethoxyquinazolinone was successively ${ }_{60}$ subjected to the reaction with 1 equiv. of butyllithium and 4 equiv. of LTMP. Functionalization of the lithio intermediates furnished the compounds 52-55, respectively. 7Chloroquinazolinone behaved similarly (compounds 56) (Scheme 33). ${ }^{27,34}$ Compounds 53 and $\mathbf{5 4}$ allowed subsequent 65 arylation through Suzuki or Stille cross-couplings.<smiles>[R]c1cc2ncnc([R])c2cc1[R]</smiles>

$\mathrm{R}^{1}=\mathrm{NHC}_{6} \mathrm{H}_{5}, \mathrm{R}^{2}=\mathrm{R}^{3}=\mathrm{OMe}$

$\mathrm{R}^{1}=4-\mathrm{MeOC}_{6} \mathrm{H}_{4}, \mathrm{R}^{2}=\mathrm{R}^{3}=\mathrm{OMe}$

$\mathrm{R}^{1}=4-\mathrm{F}_{3} \mathrm{CC}_{6} \mathrm{H}_{4}, \mathrm{R}^{2}=\mathrm{R}^{3}=\mathrm{OMe}$

$\mathrm{R}^{1}=\mathrm{OH}, \mathrm{R}^{2}=\mathrm{R}^{3}=\mathrm{OMe}$

$\mathrm{R}^{1}=\mathrm{OH}, \mathrm{R}^{2}=\mathrm{H}, \mathrm{R}^{3}=\mathrm{Cl}$<smiles>[R]c1nc(OC)c(CC)c(OC)n1</smiles>

Scheme 33 Deprotonative functionalization of 4-anilino-, 4-(4methoxyphenyl)- and 4-(4-trifluoromethylphenyl)-6,7-dimethoxyquinazoline, 6,7-dimethoxy- and 7-chloroquinazolinone. Reaction conditions: 70 [a] LTMP, THF, $-75{ }^{\circ} \mathrm{C}, 2 \mathrm{~h} ;[\mathrm{b}]$ Electrophile $\{E l\}$ : MeCHO $\{\mathrm{CH}(\mathrm{OH}) \mathrm{Me}\}, \mathrm{PhCHO}\{\mathrm{CH}(\mathrm{OH}) \mathrm{Ph}\} ;[\mathrm{c}]$ hydrolysis; [d] LTMP, THF, $75^{\circ} \mathrm{C}, 1 \mathrm{~h}$; [e] Electrophile $\{$ El $\}: \mathrm{I}_{2}\{\mathrm{I}\} ;[\mathrm{f}] \mathrm{LDA}, \mathrm{THF},-75^{\circ} \mathrm{C}, 1 \mathrm{~h} ;[\mathrm{g}]$ BuLi, THF, $-75^{\circ} \mathrm{C}, 15 \mathrm{~min}$; [h] LTMP, THF, $-75^{\circ} \mathrm{C}, 1.5 \mathrm{~h}$.

The metalation of other substituted pyrimidines has been 
only scarcely examined up to now.

\subsection{Metalation of $N$-protected aminopyrimidines}

4-(Tert-butoxycarbonyl)amino-2-(trimethylsilyl)pyrimidine was made accessible in a low $11 \%$ yield after consecutive 5 exposition of 4-(tert-butoxycarbonyl)aminopyrimidine to the action of LTMP and chlorotrimethylsilane. ${ }^{47 \mathrm{~b}}$ This remains the sole example of a pyrimidine deprotonation at the 2-position known so far.

\section{Metalation of pyrazines and quinoxalines}

\section{4.1 Metalation of bare and long range activated pyrazines}

First mentions to a pyrazine deprotonation date from 1971, when it was observed as a competitive reaction in nucleophilic addition of alkyllithiums, ${ }^{49}$ and above all $1974,{ }^{50}$ when ring metalation was observed together with lateral metalation by 15 treating 2-ethyl-3-methylpyrazine with methyllithium.

As described for pyridazine, regioselective metalation of pyrazine was found possible using 4 equiv. of LTMP and very short exposure times at $-75{ }^{\circ} \mathrm{C}$, a result evidenced by interception with benzaldehyde, acetaldehyde or elemental 20 iodine to give the functionalized pyrazines $\mathbf{5 7}$ in 39 to $65 \%$ yields. When benzaldehyde was used in excess ( 3 equiv.), the 2,5-disubstituted pyrazine $\mathbf{5 8}$ was inevitably produced, probably by competitive deprotonation of the already 2functionalized pyrazine during the trapping step (Scheme $2534)^{17}$<smiles>c1cnccn1</smiles>
$\underset{39-65 \%}{\stackrel{[a, b, c]}{\longrightarrow}}$<smiles>Clc1cnccn1</smiles>
57

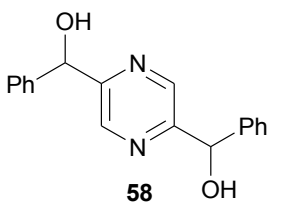

Scheme 34 Deprotonative functionalization of pyrazine. Reaction conditions: [a] LTMP, THF, $-75^{\circ} \mathrm{C}, 6 \mathrm{~min}$; [b] Electrophile $\{$ El $\}$ : $\mathrm{PhCHO}$ $\{\mathrm{CH}(\mathrm{OH}) \mathrm{Ph}\}, \mathrm{MeCHO}\{\mathrm{CH}(\mathrm{OH}) \mathrm{Me}\}, \mathrm{I}_{2}\{\mathrm{I}\} ;[\mathrm{c}]$ hydrolysis.

30 Using an in situ prepared mixture of $\mathrm{ZnCl}_{2} \cdot \mathrm{TMEDA}(0.5$ equiv.) and LTMP (1.5 equiv.) in THF, the metalated compound could be accumulated at room temperature to give after trapping the monosubstituted derivatives (e.g. iodopyrazine in $59 \%$ yield). Starting from quinoxaline 35 resulted in mixtures of 2-iodo, 2,5-diiodo and 2,2'biquinoxaline under the same reaction conditions. ${ }^{18}$

3-Chloro- $\alpha$-arylpyrazine-2-methanols got deprotonated at the 5-position upon treatment with LTMP (3 equiv.) in THF at $-75^{\circ} \mathrm{C}$, leading to the derivatives 59-63 (Scheme 35). ${ }^{51}$ High 40 yields were obtained using a similar protocol with 2,3dichloropyrazine. ${ }^{52}$ Compounds 59 and $\mathbf{6 0}(E l=\mathrm{I})$ were next functionalized using a Negishi procedure as key step to furnish septorin, the main agent of a wheat disease impeding growth.

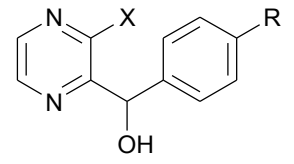

$\underset{52-64 \%}{\longrightarrow}$

$$
\mathrm{X}=\mathrm{Cl}, \mathrm{R}=\mathrm{OMe}
$$

$\mathrm{X}=\mathrm{Cl}, \mathrm{R}=\mathrm{OCH}_{2} \mathrm{OCH}_{3}$

$X=F, R=H$

$\mathrm{X}=\mathrm{F}, \mathrm{R}=\mathrm{O}\left(\mathrm{CH}_{2}\right)_{9} \mathrm{CH}_{3}$

${ }_{45} \mathrm{X}=\mathrm{F}, \mathrm{R}=\mathrm{O}\left(\mathrm{CH}_{2}\right)_{11} \mathrm{CH}_{3}$

\section{$[a, b, c]$}

$[a, b, c]$

[d,e,c]

$[d, e, c]$

[d,e,c]<smiles>[R]c1ccc(C(O)c2ncc([CH])nc2[X])cc1</smiles>

59: $52-64 \%$

60: $52 \%$

61: $84 \%$

62: $60 \%$

63: $59 \%$
Scheme 35 Deprotonative functionalization of 3-chloro- and 3-fluoro- $\alpha$ arylpyrazine-2-methanols. Reaction conditions: [a] LTMP, THF, $-75^{\circ} \mathrm{C}$, $15 \mathrm{~min} ;[\mathrm{b}]$ Electrophile $\{E l\}: \mathrm{MeCHO}\{\mathrm{CH}(\mathrm{OH}) \mathrm{Me}\}, \mathrm{PhCHO}$ $\{\mathrm{CH}(\mathrm{OH}) \mathrm{Ph}\}, \mathrm{C}_{2} \mathrm{Cl}_{6}\{\mathrm{Cl}\}, \mathrm{I}_{2}\{\mathrm{I}\} ;[\mathrm{c}]$ hydrolysis; [d] LTMP, THF, $-75^{\circ} \mathrm{C}$, $505 \mathrm{~min}$; [e] Electrophile $\{$ El $\}: \mathrm{I}_{2}\{\mathrm{I}\}$.

2-Fluoro-3-phenylpyrazine was similarly deprotonated (3 equiv. of LTMP), as demonstrated by trapping with most of the electrophiles to afford the 6-substituted derivatives 64 . When elemental iodine was used, the 6-iodo compound $\mathbf{6 5}$ 55 was isolated only when 1 equiv. of LTMP was employed. Using LTMP in excess ( 3 equiv.) and 1 equiv. of iodine, the 5 -iodo compound $\mathbf{6 6}$ was formed instead. The latter could result from a deprotonation of the 6-substituted derivatives $\mathbf{6 5}$ with the excess of LTMP during the quenching step with ${ }_{60}$ iodine, followed by iodine migration, as depicted in Scheme $36^{51 \mathrm{~b}, 53}$

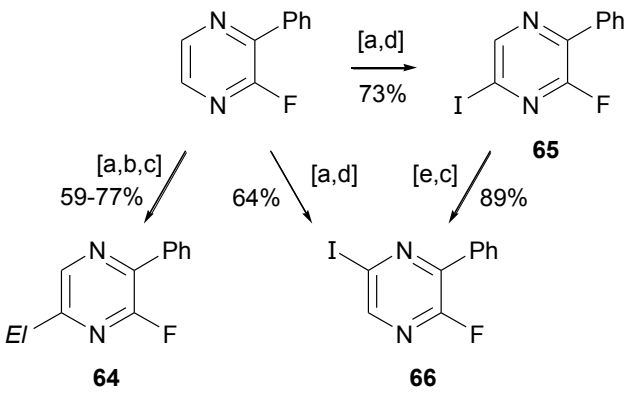

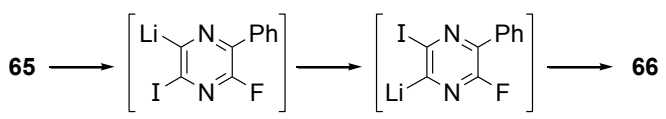

Scheme 36 Deprotonative functionalization of 2-fluoro-3-phenylpyrazine. Reaction conditions: [a] LTMP, THF, $-75{ }^{\circ} \mathrm{C}, 5 \mathrm{~min}$; [b] Electrophile ${ }_{65}\{E l\}: \mathrm{MeCHO}\{\mathrm{CH}(\mathrm{OH}) \mathrm{Me}\}, \mathrm{PhCHO}\{\mathrm{CH}(\mathrm{OH}) \mathrm{Ph}\}, \mathrm{Me}_{3} \mathrm{SiCl}\left\{\mathrm{SiMe}_{3}\right\}$, $\mathrm{Bu}_{3} \mathrm{SnCl}\left\{\mathrm{SnBu}_{3}\right\} ;[\mathrm{c}]$ hydrolysis; [d] Electrophile $\{$ El $\}: \mathrm{I}_{2}\{\mathrm{I}\} ;[\mathrm{e}] \mathrm{LTMP}$, THF, $-75^{\circ} \mathrm{C}, 30 \mathrm{~min}$.

\subsection{Metalation of pyrazine-1-oxides}

Base and solvent optimization for the deprotonation of 2,5-di70 sec-butylpyrazine-1-oxide was carried out at low temperature. The best results were obtained using LTMP in THF in the presence of TMEDA. The method was extended to other substrates, affording the corresponding 2 -substituted pyrazine1 -oxides 67 in good yields (Scheme 37). ${ }^{54}$ 
<smiles>[R]c1c[n+]([O-])c([R])c([R])n1</smiles>

$\mathrm{R}^{1}=\mathrm{R}^{3}={ }^{i} \mathrm{Pr} ; \mathrm{R}^{2}=\mathrm{H}$

$R^{1}=R^{3}={ }^{s} B u ; R^{2}=H$

$\mathrm{R}^{1}=\mathrm{R}^{2}=\mathrm{C}_{6} \mathrm{H}_{5} ; \mathrm{R}^{3}=\mathrm{H}$

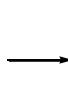

$[a, b]$

$[a, c, d]$

$[a, e, d]$<smiles></smiles>

67

$60-72 \%$

$65-74 \%$

$55 \%$

Scheme 37 Deprotonative functionalization of pyrazine-1-oxide. Reaction conditions: [a] LTMP, THF, TMEDA, $-75^{\circ} \mathrm{C}, 20 \mathrm{~min}$; [b] Electrophile $\{E l\}: \quad \mathrm{HCO}_{2} \mathrm{Me} \quad\{\mathrm{CHO}\}, \quad 4-\mathrm{MeC}_{6} \mathrm{H}_{4} \mathrm{COCl} \quad\left\{\mathrm{C}(\mathrm{O})\left(4-\mathrm{MeC}_{6} \mathrm{H}_{4}\right)\right\}$, 4${ }_{5} \mathrm{MeC}_{6} \mathrm{H}_{4} \mathrm{CO}_{2} \mathrm{Me} \quad\left\{\mathrm{C}(\mathrm{O})\left(4-\mathrm{MeC}_{6} \mathrm{H}_{4}\right)\right\} ;$ [c] Electrophile $\{$ El $\}$ : EtCHO $\{\mathrm{CH}(\mathrm{OH}) \mathrm{Et}\}, \mathrm{PhCHO}\{\mathrm{CH}(\mathrm{OH}) \mathrm{Ph}\} ;$ [d] hydrolysis; [e] Electrophile $\{$ El\}: $\mathrm{PhCHO}\{\mathrm{CH}(\mathrm{OH}) \mathrm{Ph}\}$.

\subsection{Metalation of halo- pyrazines and quinoxalines}

Bromopyrazine was deprotonated next to the bromo group 10 using 3 equiv. of LDA in THF at $-75^{\circ} \mathrm{C}$. This was evidenced by quenching after $15 \mathrm{~min}$ with acetaldehyde, benzaldehyde, phenyl disulfide or elemental iodine to give the expected products 68 in $62,69,53$ and $50 \%$ yield, respectively. ${ }^{20}$ Chloro- and iodopyrazine were similarly regioselectively 15 metalated, but LTMP proved to be a better base than LDA. Due to the better stability of 2-chloro-3-lithiopyrazine, the accumulation time could be extended to $30 \mathrm{~min}$ (no change was observed using longer exposure times) to give the 3functionalized chloropyrazines 69 in satisfying yields. ${ }^{55}$ In 20 contrast, the accumulation time was shortened with iodopyrazine in order to obtain the 3-substituted 2iodopyrazines $\mathbf{7 0}$ in satisfying yields ${ }^{46}$ (Scheme 38). The metalation next to the iodo group was extended to a disubstituted iodopyrazine. ${ }^{48 a}$

$\begin{array}{lll} & \\ & & \\ X=B r & {[a, b, c]} & 68: 50-69 \% \\ X=C l & {[d, e, c]} & 69: 55-90 \% \\ X=1 & {[f, g, c]} & 70: 19-82 \%\end{array}$

Scheme 38 Deprotonative functionalization of iodo-, bromo- and chloropyrazine. Reaction conditions: [a] LDA, THF, $-75^{\circ} \mathrm{C}, 15 \mathrm{~min}$; [b] Electrophile $\{$ El $\}$ : $\mathrm{MeCHO}\{\mathrm{CH}(\mathrm{OH}) \mathrm{Me}\}, \mathrm{PhCHO}\{\mathrm{CH}(\mathrm{OH}) \mathrm{Ph}\},(\mathrm{PhS})_{2}$ $\{\mathrm{SPh}\}, \mathrm{I}_{2}\{\mathrm{I}\} ;[\mathrm{c}]$ hydrolysis; [d] LTMP, THF, $-70{ }^{\circ} \mathrm{C}, 30 \mathrm{~min} ;[\mathrm{e}]$ 30 Electrophile $\{E l\}: \quad \mathrm{DCl} \quad\{\mathrm{D}\}, \quad \mathrm{MeCHO} \quad\{\mathrm{CH}(\mathrm{OH}) \mathrm{Me}\}, \quad \mathrm{PhCHO}$ $\{\mathrm{CH}(\mathrm{OH}) \mathrm{Ph}\}, \quad 2$-furylCHO $\{\mathrm{CH}(\mathrm{OH})(2$-furyl $)\}, \quad 4-\mathrm{MeOC}_{6} \mathrm{H}_{4} \mathrm{CHO}$ $\left\{\mathrm{CH}(\mathrm{OH})\left(4-\mathrm{MeOC}_{6} \mathrm{H}_{4}\right)\right\}, \quad 2-\mathrm{MeOC}_{6} \mathrm{H}_{4} \mathrm{CHO} \quad\left\{\mathrm{CH}(\mathrm{OH})\left(2-\mathrm{MeOC}_{6} \mathrm{H}_{4}\right)\right\}$, $\mathrm{Ph}_{2} \mathrm{CO}\left\{\mathrm{C}(\mathrm{OH}) \mathrm{Ph}_{2}\right\}, \mathrm{HCO}_{2} \mathrm{Et}\{\mathrm{CHO}\} ;\left[\right.$ [f] LTMP, THF, $-75{ }^{\circ} \mathrm{C}, 5 \mathrm{~min}$; [g] Electrophile $\{$ El\}: $\mathrm{MeCHO}\{\mathrm{CH}(\mathrm{OH}) \mathrm{Me}\}, \mathrm{PhCHO}\{\mathrm{CH}(\mathrm{OH}) \mathrm{Ph}\}$, ${ }_{35} \mathrm{Ph}_{2} \mathrm{CO}\left\{\mathrm{C}(\mathrm{OH}) \mathrm{Ph}_{2}\right\},(\mathrm{PhS})_{2}\{\mathrm{SPh}\}, \mathrm{HCO}_{2} \mathrm{Et}\{\mathrm{CHO}\}, \mathrm{Me}_{3} \mathrm{SiCl}\left\{\mathrm{SiMe}_{3}\right\}$, $\mathrm{CO}_{2}\left\{\mathrm{CO}_{2} \mathrm{H}\right\}, \mathrm{I}_{2}\{\mathrm{I}\}$.

Metalation of chloropyrazines next to the halogen still proved feasible when a substituent such as a ketal or an aryl group was present at the 6-position. ${ }^{52}$

40 The metalation/functionalization sequence was applied to 2,6-dichloropyrazine to give the compounds $\mathbf{7 1}$ in moderate to good yields. Nevertheless, the outcome of the reaction largely depends on the amount of base used since the formation of 3,5-difunctionalized products $\mathbf{7 2}$ could not be avoided using 45 an excess of metalating agent and electrophiles compatible

with in situ trapping such as benzaldehyde, elemental iodine or chlorotributylstannane (Scheme 39). ${ }^{55 c, 56}$<smiles>Clc1cncc(Cl)n1</smiles><smiles>Clc1nc(Cl)c(Cl)nc1Cl</smiles>

Scheme 39 Deprotonative functionalization of 2,6-dichloropyrazine. 50 Reaction conditions: [a] LTMP, THF, $-70{ }^{\circ} \mathrm{C}, 2 \mathrm{~h}$; [b] Electrophile $\{$ El\}: $\mathrm{MeCHO}\{\mathrm{CH}(\mathrm{OH}) \mathrm{Me}\}, \mathrm{EtCHO}\{\mathrm{CH}(\mathrm{OH}) \mathrm{Et}\}, \mathrm{PhCHO}\{\mathrm{CH}(\mathrm{OH}) \mathrm{Ph}\}, 2-$ $\mathrm{MeOC}_{6} \mathrm{H}_{4} \mathrm{CHO} \quad\left\{\mathrm{CH}(\mathrm{OH})\left(2-\mathrm{MeOC}_{6} \mathrm{H}_{4}\right)\right\}, \quad$ 2,4-diClC $\mathrm{H}_{6} \mathrm{H}_{3} \mathrm{CHO}$ $\left\{\mathrm{CH}(\mathrm{OH})\left(2,4-\mathrm{diClC}_{6} \mathrm{H}_{3}\right)\right\}, \mathrm{HCO}_{2} \mathrm{Et}\{\mathrm{CHO}\}, \mathrm{I}_{2}\{\mathrm{I}\}, \mathrm{Me}_{3} \mathrm{SnCl}\left\{\mathrm{SnMe}_{3}\right\} ;$ [c] hydrolysis.

55 2,6-Dichloropyrazine could serve as attractive starting material as it offered the possibility to replace one hydrogen by a first electrophile and the other one by a second electrophile. The dideprotonation was optimized using 2.5 equiv. of LTMP in THF at $-100{ }^{\circ} \mathrm{C}$, and the sequential 60 introduction of two different electrophiles allowed the synthesis of 2,6-dichloro-3,5-disubstituted compounds including 73 (Scheme 40). ${ }^{57}$<smiles>Clc1cncc(Cl)n1</smiles>
$\underset{73 \%}{\stackrel{[a, b, c]}{\longrightarrow}}$<smiles>O=C(O)C1O[C@@](O)(c2nc(I)c(Cl)nc2Cl)C(Br)[C@@H]1OCc1ccccc1</smiles>

Scheme 40 Deprotonative functionalization of 2,6-dichloropyrazine. 65 Reaction conditions: [a] LTMP, THF, $-100{ }^{\circ} \mathrm{C}, 1 \mathrm{~h}$; [b] First electrophile: $\mathrm{I}_{2}$; [c] Second electrophile: 2,3,5-tri- $O$-benzyl-D-ribono-1,4-lactone.

The situation becomes more complex when one has to metalate 2-chloroquinoxaline. First attempts to use LTMP were unsuccessful. ${ }^{56 a}$ The reaction was next shown to provide 70 the 3,3'-dimer in 59\% yield when DCl was used to quench the lithio intermediate. 3-Substituted derivatives were obtained after reaction of LTMP at $-75{ }^{\circ} \mathrm{C}$ for $15-20 \mathrm{~min}$ and subsequent trapping with acetaldehyde or benzaldehyde in medium yields. ${ }^{58}$

75 Fluoropyrazine proved prone to proton abstraction next to the halogen when treated with hindered lithium dialkylamides ( 1 equiv.) in THF at low temperatures, LTMP giving the best yields with a short contact time of 5 min (compounds 74). 3 Fluoro- $\alpha, \alpha$-diphenylpyrazine-2-methanol was subjected to 80 deprotonation too when allowed to react with LTMP at low temperature to give the compounds $\mathbf{7 5}$ (Scheme 41). When the reaction from fluoropyrazine was conducted in the presence of an excess of base and chlorotributylstannane at $-100{ }^{\circ} \mathrm{C}, 2$ fluoro-3,6-bis(tributylstannyl)pyrazine, which probably 85 results from deprotonation at C6 of intermediate 2-fluoro-3(tributylstannyl)pyrazine under the in situ trapping conditions used, was isolated in $90 \%$ yield. ${ }^{53,59}$ 


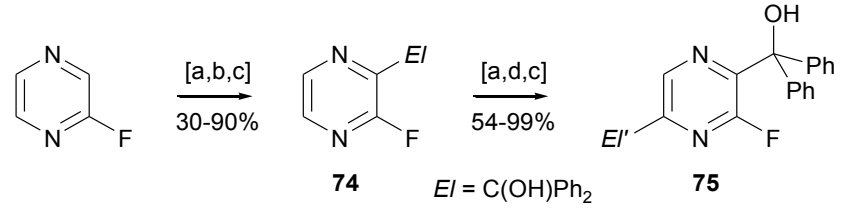

Scheme 41 Deprotonative functionalization of fluoropyrazine and 3fluoro- $\alpha, \alpha$-diphenylpyrazine-2-methanol. Reaction conditions: [a] LTMP, THF, $-75{ }^{\circ} \mathrm{C}, 5 \mathrm{~min}$; [b] Electrophile $\{$ El\}: $\mathrm{MeCHO}\{\mathrm{CH}(\mathrm{OH}) \mathrm{Me}\}$, $5 \mathrm{PhCHO}\{\mathrm{CH}(\mathrm{OH}) \mathrm{Ph}\}, \mathrm{Ph}_{2} \mathrm{CO}\left\{\mathrm{C}(\mathrm{OH}) \mathrm{Ph}_{2}\right\}, 2$-furylCHO $\{\mathrm{CH}(\mathrm{OH})(2-$ furyl)\}, 4- $\mathrm{MeOC}_{6} \mathrm{H}_{4} \mathrm{CHO} \quad\left\{\mathrm{CH}(\mathrm{OH})\left(4-\mathrm{MeOC}_{6} \mathrm{H}_{4}\right)\right\}, 2-\mathrm{MeOC}_{6} \mathrm{H}_{4} \mathrm{CHO}$ $\left\{\mathrm{CH}(\mathrm{OH})\left(2-\mathrm{MeOC}_{6} \mathrm{H}_{4}\right)\right\}, \mathrm{HCO}_{2} \mathrm{Et}\{\mathrm{CHO}\},(\mathrm{PhS})_{2}\{\mathrm{SPh}\}, \mathrm{I}_{2}\{\mathrm{I}\}, \mathrm{BrCN}$ $\{\mathrm{Br}\}, \mathrm{MeCONMe}_{2}\{\mathrm{C}(\mathrm{O}) \mathrm{Me}\}, \mathrm{PhCONMe}_{2}\{\mathrm{COPh}\} ;[\mathrm{c}]$ hydrolysis; [d] Electrophile $\left\{\right.$ El\}: $\mathrm{Ph}_{2} \mathrm{CO}\left\{\mathrm{C}(\mathrm{OH}) \mathrm{Ph}_{2}\right\}, \mathrm{MeCHO}\{\mathrm{CH}(\mathrm{OH}) \mathrm{Me}\}, \mathrm{Me}_{3} \mathrm{SiCl}$ $10\left\{\mathrm{SiMe}_{3}\right\}, \mathrm{I}_{2}\{\mathrm{I}\}, \mathrm{C}_{2} \mathrm{Cl}_{6}\{\mathrm{Cl}\}$.

Chloro- and fluoropyrazine were also functionalized at the 6-position using a trick. When treated with 3 equiv. of LTMP in $\mathrm{THF}$ at $-100{ }^{\circ} \mathrm{C}$ in the presence of 1 equiv. of chlorotributylstannane, the 3-(tributylstannyl) compounds $\mathbf{7 6}$ 15 first formed could be converted to the 6-lithio compound which, via migration of the tributylstannyl group, could finally afford 2-halo-6-(tributylstannyl)pyrazines 77 after hydrolysis (Scheme 42). ${ }^{52,53}$<smiles>[X]c1cnccn1</smiles>

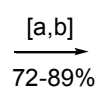<smiles>C1CC1</smiles><smiles>[X]c1nc([Al]C)cnc1SCCC</smiles>

76

20 Scheme 42 Deprotonative functionalization of chloro- and fluoropyrazine. Reaction conditions: [a] $\mathrm{Bu}_{3} \mathrm{SnCl}, \mathrm{LTMP}, \mathrm{THF},-100{ }^{\circ} \mathrm{C}$ to $-40^{\circ} \mathrm{C}, 2.5 \mathrm{~h}$; [b] hydrolysis.

Similar protocols enabled the metalation of 2-fluoro-6(tributylstannyl)pyrazine and 2-fluoro-6-arylpyrazines at the 253 -position. ${ }^{53}$ By intercepting the lithio compounds of the latter with iodine, subsequent Sonogashira, Negishi and Suzuki cross-couplings proved possible. Deprotonation of 2-chloro-6methoxypyrazine showed incomplete regioselectivity using LDA or LTMP in THF at $-70{ }^{\circ} \mathrm{C}$, with a 15:85 ratio in favor 30 of the 5-position next to the methoxy group. ${ }^{55 \mathrm{~b}, \mathrm{c}}$ Recourse to very hindered base lithium $N$-tert-butyl- $N$-(1isopropylpentyl)amide $\left(\mathrm{LB}_{1}\right)$ lowered the regioselectivity at the position adjacent to the methoxy group. ${ }^{22}$ Replacing the chloro group with an iodo resulted in a complete 35 regioselectivity when LDA was used in THF at $-70{ }^{\circ} \mathrm{C}$. ${ }^{55 \mathrm{~b}}$

When 2-fluoro-6-methoxypyrazine was allowed to react with LDA in THF at $-70{ }^{\circ} \mathrm{C}$ for $5 \mathrm{~min}$, trapping with aldehydes showed deprotonation mainly occurred next to the fluoro group (96:4 ratio); LTMP and $N$-tert-butyl- $N$-(140 isopropylpentyl)amide $\left(\mathrm{LB}_{1}\right)$ gave lower selectivities. ${ }^{22}$

6-Chloro-2,3-dimethoxyquinoxaline features an interesting case of regioselectivity. Treatment with LTMP (4 equiv.) in THF for $1 \mathrm{~h}$ at low temperature followed by reaction with electrophiles afforded the 5-substituted quinoxalines as major ${ }_{45}$ products ( $85 \%$ yield using benzaldehyde as the electrophile). In the absence of directing group on the benzene ring of quinoxaline, e.g. with 2-methoxy-3-phenylquinoxaline, the reaction took place at both the 5 - and 8 -positions. ${ }^{27}$

\subsection{Metalation of alkoxy- pyrazines and quinoxalines}

${ }_{50}$ LTMP-promoted metalation of 2-methoxy and 2,6dimethoxypyrazine was carried out in THF at $0{ }^{\circ} \mathrm{C}$ or $-75^{\circ} \mathrm{C}$ to give the compounds $\mathbf{7 8 - 7 9}$ after electrophilic trapping (Scheme 43). ${ }^{25 b, 28 a, 29,55 b, c, 56,60}$ As previously noted for 3,6dimethoxypyridazine, good yields were obtained with 55 electrophiles sufficiently compatible with the base (1 equiv.) to allow in situ trapping. ${ }^{28 a}$ This statement was confirmed by successive treatment of 2,6-dimethoxypyrazine with LTMP (1 equiv.) at $0{ }^{\circ} \mathrm{C}$ for $15 \mathrm{~min}$, and deuterated ethanol, which afforded the 3-deuterated compound in a low $32 \%$ conversion. ${ }_{60}$ Using 2 equiv. of base had a positive effect on the conversion (83\% after $15 \mathrm{~min}$ and $100 \%$ after $30 \mathrm{~min}){ }^{56 \mathrm{~b}}$<smiles>[R]c1cncc(OC)n1</smiles>

$\mathrm{R}=\mathrm{H}, \mathrm{OMe}$

$\mathrm{R}=\mathrm{H}, \mathrm{OMe}$

$$
\mathrm{R}=\mathrm{OMe}
$$

Scheme 43 Deprotonative functionalization of 2-methoxy- and 2,6dimethoxypyrazine. Reaction conditions: [a] LTMP, THF, $-75{ }^{\circ} \mathrm{C}$; [b] 65 Electrophile $\left\{\right.$ El\}: $\mathrm{PhCHO}\{\mathrm{CH}(\mathrm{OH}) \mathrm{Ph}\}, \mathrm{MeI}\{\mathrm{Me}\}, \mathrm{Me}_{3} \mathrm{SiCl}\left\{\mathrm{SiMe}_{3}\right\}$; [c] hydrolysis; [d] Electrophile $\{E l\}$ : $\mathrm{MeCHO}\{\mathrm{CH}(\mathrm{OH}) \mathrm{Me}\}, \mathrm{PhCHO}$ $\{\mathrm{CH}(\mathrm{OH}) \mathrm{Ph}\}, \mathrm{PhCON}(\mathrm{OMe}) \mathrm{Me}\{\mathrm{COPh}\}, \mathrm{I}_{2}\{\mathrm{I}\} ;[\mathrm{e}] \mathrm{LTMP}, \mathrm{THF}, 0{ }^{\circ} \mathrm{C}$, $45 \mathrm{~min}$; [f] Electrophile $\{$ El $\}: \mathrm{DCl}\{\mathrm{D}\}, \mathrm{MeCHO}\{\mathrm{CH}(\mathrm{OH}) \mathrm{Me}\}, \mathrm{PhCHO}$ $\{\mathrm{CH}(\mathrm{OH}) \mathrm{Ph}\}, \quad 2-\mathrm{MeOC}_{6} \mathrm{H}_{4} \mathrm{CHO} \quad\left\{\mathrm{CH}(\mathrm{OH})\left(2-\mathrm{MeOC}_{6} \mathrm{H}_{4}\right)\right\}, \quad \mathrm{HCO}_{2} \mathrm{Et}$ $70\{\mathrm{CHO}\}, \mathrm{PhCON}(\mathrm{OMe}) \mathrm{Me}\{\mathrm{COPh}\}, \mathrm{I}_{2}\{\mathrm{I}\}, \mathrm{MeOCOCl}\left\{\mathrm{CO}_{2} \mathrm{Me}\right\}$.

The method using LTMP in THF at $-75^{\circ} \mathrm{C}$ was extended to 2-methoxyquinoxaline (interception of the lithio compound with $N$-methoxy- $N$-methylbenzamide in $43 \%$ yield). ${ }^{56 a}$ A more complete investigation showed the yields of the 3 -substituted 75 derivatives $\mathbf{8 0}$ were limited by the competitive formation of the dimer $\mathbf{8 1}$ (Scheme 44). ${ }^{58}$<smiles>COc1cnc2ccccc2n1</smiles><smiles>[TeH4]</smiles><smiles>CCc1nc2ccccc2nc1OC</smiles>

80: $44-70 \%$<smiles>[2H]c1nc2ccccc2nc1OC</smiles>

81: $9-53 \%$
Scheme 44 Deprotonative functionalization of 2-methoxyquinoxaline. Reaction conditions: [a] LTMP, THF, $-70{ }^{\circ} \mathrm{C}, 2 \mathrm{~h}$; [b] Electrophile $\{$ El $\}$ : $80 \mathrm{DCl} / \mathrm{EtOD}\{\mathrm{D}\}, \mathrm{MeCHO}\{\mathrm{CH}(\mathrm{OH}) \mathrm{Me}\}, \mathrm{PhCHO}\{\mathrm{CH}(\mathrm{OH}) \mathrm{Ph}\}, 2-$ $\mathrm{MeOC}_{6} \mathrm{H}_{4} \mathrm{CHO}\left\{\mathrm{CH}(\mathrm{OH})\left(2-\mathrm{MeOC}_{6} \mathrm{H}_{4}\right)\right\}, \mathrm{Ph}_{2} \mathrm{CO}\left\{\mathrm{C}(\mathrm{OH}) \mathrm{Ph}_{2}\right\}, \mathrm{I}_{2}\{\mathrm{I}\} ;[\mathrm{c}]$ hydrolysis.

The dideprotonation of several pyrazine-2,5-diketals was achieved using LTMP in THF at $-25{ }^{\circ} \mathrm{C}$ for $4 \mathrm{~h}$, as 85 demonstrated by subsequent reaction with elemental iodine to afford the compounds 82 (Scheme 45). ${ }^{61}$ The reagent has to be used in large excess (12 equiv.) which consumes large amounts of the electrophile and limits the scale. 
<smiles>[R]C1(c2cnc(C3([R])OCC(C)(C)CO3)cn2)OCC(C)(C)CO1</smiles>

$\underset{47-84 \%}{[a, b, c]}$

$\mathrm{R}=\mathrm{Bu}, \mathrm{C}_{12} \mathrm{H}_{25}, 4-{ }^{\mathrm{t}} \mathrm{BuC}_{6} \mathrm{H}_{4}, 4-\mathrm{C}_{12} \mathrm{H}_{25} \mathrm{C}_{6} \mathrm{H}_{4}$

82

Scheme 45 Deprotonative functionalization of pyrazine-2,5-diketals. Reaction conditions: [a] LTMP, THF, $-25^{\circ} \mathrm{C}, 4 \mathrm{~h}$; [b] $\mathrm{I}_{2}$; [c] hydrolysis.

4.5 Metalation of sulfanyl-, sulfinyl- and sulfonyl- pyrazines 5 and quinoxalines

Methylsulfanyl- and phenylsulfanylpyrazine have been deprotonated using LTMP in THF at $-75{ }^{\circ} \mathrm{C}$. The reaction occurred at the 3-position, leading to the compound $\mathbf{8 3}$ (Scheme 46). ${ }^{56 a, 30}$ The method was extended to 210 (methylsulfanyl)quinoxaline (interception of the lithio compound with $N$-methoxy- $N$-methylbenzamide in $42 \%$ yield). ${ }^{56 \mathrm{a}}$<smiles>[R]c1cnccn1</smiles>

$$
\mathrm{R}=\mathrm{Me}
$$

$\mathrm{R}=\mathrm{Ph}$

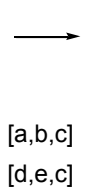

$[\mathrm{d}, \mathrm{e}, \mathrm{c}]$<smiles>[R7]c1nccnc1[CH]</smiles>

83: $76 \%$

83: $74 \%$
Scheme 46 Deprotonative functionalization of methylsulfanyl- and 15 phenylsulfanylpyrazine. Reaction conditions: [a] LTMP, THF, $-75^{\circ} \mathrm{C}, 20$ min; [b] Electrophile $\{E l\}: \mathrm{PhCON}(\mathrm{OMe}) \mathrm{Me}\{\mathrm{COPh}\}$; [c] hydrolysis; [d] LTMP, THF, $-75^{\circ} \mathrm{C}, 1 \mathrm{~h}$; [e] Electrophile $\{$ El $\}$ : MeCHO $\{\mathrm{CH}(\mathrm{OH}) \mathrm{Me}\}$.

Whereas methylsulfinyl- and methylsulfonylpyrazine were mainly deprotonated on the methyl group upon treatment with ${ }_{20}$ LTMP, phenylsulfonylpyrazine underwent ring deprotonation using LDA to give after transformation the 3-substituted derivative in $33 \%$ yield. $^{30}$ Tert-butylsulfinyl- and tertbutylsulfonylpyrazine similarly led to the 3-substituted derivatives 84 in modest yields (Scheme 47). ${ }^{31}$<smiles>CCCCOc1cnccn1</smiles>

$25 x=1,2$

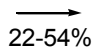

$[a, b, c]$

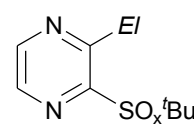

84
Scheme 47 Deprotonative functionalization of sulfinyl- and sulfonylpyrazine. Reaction conditions: [a] LTMP or LDA, THF, $-75^{\circ} \mathrm{C}$, $30 \mathrm{~min} ;[\mathrm{b}]$ Electrophile $\{E l\}$ : $\mathrm{MeCHO}\{\mathrm{CH}(\mathrm{OH}) \mathrm{Me}\}, \mathrm{PhCHO}$ $\{\mathrm{CH}(\mathrm{OH}) \mathrm{Ph}\}, \mathrm{I}_{2}\{\mathrm{I}\} ;[\mathrm{c}]$ hydrolysis.

\section{${ }_{30} 4.6$ Metalation of $N$-protected amino- pyrazines and quinoxalines}

The metalation of $\mathrm{N}$-pivaloyl protected aminopyrazine was unsuccessfully attempted using butyl-, tert-butyl- and mesityllithium due to easier nucleophilic addition. Recourse 35 to LTMP ( 2 equiv.) resulted in an incomplete metalation at the 3-position when used in THF at $0{ }^{\circ} \mathrm{C}$, as demonstrated by quenching with benzaldehyde to give after hydrolysis the expected alcohol in $25 \%$ yield. ${ }^{62}$ Deprotonation of $\mathrm{N}$-tertbutoxycarbonyl diprotected 2,5-diaminopyrazine was 40 achieved using 8 equiv. of the mixed $\mathrm{Li}-\mathrm{K}$ system obtained by mixing LTMP and potassium tert-butoxide, after replacement of the carbamate protons by tributylstannyl groups, as evidenced by interception with chlorotributylstannane (Scheme 48). ${ }^{61}$ Subsequent $\mathrm{Pd} / \mathrm{Cu}$ couplings with 45 diiodopyrazines $\mathbf{8 2}$ were utilized to prepare polymers.
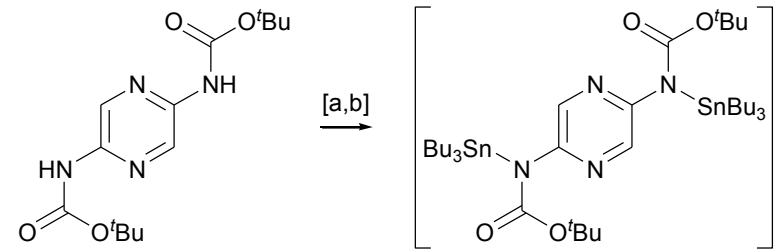

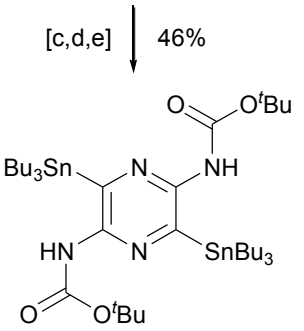

Scheme 48 Deprotonative functionalization of $N$-tert-butoxycarbonyl diprotected 2,5-diaminopyrazine. Reaction conditions: [a] $\mathrm{NaH}, \mathrm{THF}, \mathrm{rt}$, $1 \mathrm{~h}$; [b] $\mathrm{Bu}_{3} \mathrm{SnCl}, \mathrm{rt}, 15 \mathrm{~min}$; [c] LTMP, ${ }^{\mathrm{t}} \mathrm{BuOK}, \mathrm{DEE}, \mathrm{rt}, 3 \mathrm{~h}$; [d] ${ }_{50} \mathrm{Bu}_{3} \mathrm{SnCl}$, rt, overnight; [e] hydrolysis.

Treatment of $\mathrm{N}$-pivaloyl protected 2-aminoquinoxaline with LTMP in THF at $-70{ }^{\circ} \mathrm{C}$ resulted in the regioselective metalation next to the directing group to afford after trapping the 3 -substituted derivatives $\mathbf{8 5}$ (Scheme 49 ). ${ }^{58}$

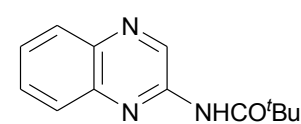

55

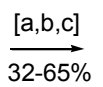<smiles>CCCCCCC(=O)Nc1nc2ccccc2nc1Cl</smiles>

85
Scheme 49 Deprotonative functionalization of $N$-pivaloyl 2-aminoquinoxaline. Reaction conditions: [a] LTMP, THF, $-70{ }^{\circ} \mathrm{C}, 2.5 \mathrm{~h}$; [b] Electrophile $\left\{\right.$ El\}: $\mathrm{MeCHO}\{\mathrm{CH}(\mathrm{OH}) \mathrm{Me}\}, \mathrm{PhCHO}\{\mathrm{CH}(\mathrm{OH}) \mathrm{Ph}\}, \mathrm{I}_{2}\{\mathrm{I}\}$, $\mathrm{CO}_{2}\left\{\mathrm{CO}_{2} \mathrm{H}\right\} ;[\mathrm{c}]$ hydrolysis.

\section{${ }_{60} 4.7$ Metalation of pyrazinecarboxamides and pyrazinethiocarboxamides}

Reactions between $N$-(tert-butyl)pyrazinecarboxamide and LTMP were conducted in THF at temperatures between -80 ${ }^{\circ} \mathrm{C}$ and $0{ }^{\circ} \mathrm{C}$ prior to deuteriolysis. Whereas mixtures where 65 the 5 -deuterated derivative $\mathbf{8 6}$ predominates were obtained at very low temperatures ( $45 \%$ of $\mathbf{8 6}$ against $25 \%$ of $\mathbf{8 7}(E l=\mathrm{D})$ at $-80{ }^{\circ} \mathrm{C}$ ) probably via a kinetic lithio compound at $\mathrm{C} 5$, the 3-deuterated compound $87(E l=\mathrm{D})$ was detected at $0{ }^{\circ} \mathrm{C}(4$ equiv. of base) as the only product probably via a 70 thermodynamic lithio compound at C3, stabilized by the chelating deprotonated carboxamide function. Subsequent functionalization of the deprotonated site was next considered (Scheme 50). ${ }^{62}$ 


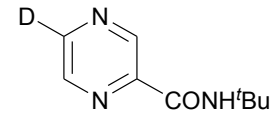

86

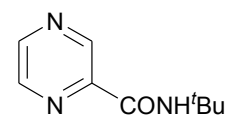

$\underset{45-75 \%}{\stackrel{[a, b, c]}{\longrightarrow}}$

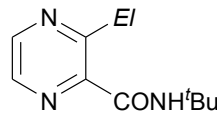

87

Scheme 50 Deprotonative functionalization of $N$-(tert-butyl)pyrazinecarboxamide. Reaction conditions: [a] LTMP, THF, $0{ }^{\circ} \mathrm{C}, 1 \mathrm{~h}$; [b] Electrophile $\{E l\}$ : DCl/EtOD $\{\mathrm{D}\}, \mathrm{MeCHO}\{\mathrm{CH}(\mathrm{OH}) \mathrm{Me}\}, \mathrm{PhCHO}$ $5\{\mathrm{CH}(\mathrm{OH}) \mathrm{Ph}\} ;[\mathrm{c}]$ hydrolysis.

Starting from $N$-methyl-, $N$-(tert-butyl)- and $N, N$ diisopropylpyrazinethiocarboxamide, a complete regioselectivity in favor of the kinetic 5-lithio intermediate was observed at low temperature, leading to the compounds ${ }_{10} \mathbf{8 8}$ (Scheme 51). ${ }^{63}$

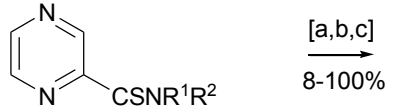

$\left(\mathrm{R}^{1}, \mathrm{R}^{2}\right)=(\mathrm{H}, \mathrm{Me}),\left(\mathrm{H},{ }^{\mathrm{t}} \mathrm{Bu}\right),\left({ }^{\mathrm{i}} \mathrm{Pr},{ }^{\mathrm{i}} \mathrm{Pr}\right)$

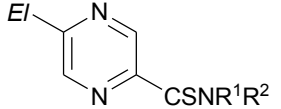

88
Scheme 51 Deprotonative functionalization of $N$-methyl-, $N$-(tert-butyl)and $N, N$-diisopropylpyrazinethiocarboxamide. Reaction conditions: [a] LTMP, THF, $-75{ }^{\circ} \mathrm{C}, 1.5 \mathrm{~h}$; [b] Electrophile $\{E l\}$ : DCl/EtOD $\{\mathrm{D}\}$, $15 \mathrm{MeCHO}\{\mathrm{CH}(\mathrm{OH}) \mathrm{Me}\}, \mathrm{PhCHO}\{\mathrm{CH}(\mathrm{OH}) \mathrm{Ph}\}, \mathrm{Ph}_{2} \mathrm{CO}\left\{\mathrm{C}(\mathrm{OH}) \mathrm{Ph}_{2}\right\}$, $\mathrm{C}_{2} \mathrm{Cl}_{6}\{\mathrm{Cl}\}, \mathrm{Bu}_{3} \mathrm{SnCl}\left\{\mathrm{SnBu}_{3}\right\}, \mathrm{MeI}\{\mathrm{Me}\}, \mathrm{Me}_{3} \mathrm{SiCl}\left\{\mathrm{SiMe}_{3}\right\}, \mathrm{I}_{2}\{\mathrm{I}\}$, $(\mathrm{PhS})_{2}\{\mathrm{SPh}\} ;[\mathrm{c}]$ hydrolysis.

\section{Conclusions}

The methods outlined above allowed the functionalization of 20 numerous diazines, and hence opened an entry to a great variety of building blocks, e.g. if combined with other reactions such as cross-couplings. ${ }^{64}$

Despite all the applications so far featured, problems remain.

The tendency of the substrates to undergo nucleophilic 25 additions or substitutions limits the scope of the reaction. Recourse to LTMP to perform these reactions reduces nucleophilic attacks of the base to the substrate, but is helpless to prevent reactions from the lithiated substrate. In addition, reactions using LTMP are equilibria, and an excess 30 of base is in general required to ensure satisfying yields.

Recently, new bases such as magnesates and zincates started to emerge, and proved convenient to allow reactions that were not accessible using lithium bases. The scope of these bases for the deprotonation of heterocycles, so far 35 demonstrated with very sensible substrates such as bare diazines and halo pyrimidines deserves to be tested further.

\section{Notes and references}

Synthèse et ElectroSynthèse Organiques, Université de Rennes 1, CNRS, Bâtiment 10A, Case 1003, Campus scientifique de Beaulieu, F-35042 40 Rennes, France.

E-mail: florence.mongin@univ-rennes1.fr; Fax: +33-2-23-23-69-55
1 T. Eicher, S. Hauptmann and A. Speicher, The Chemistry of Heterocycles, $2^{\text {nd }}$ ed., Wiley-VCH, 2003, Chapter 6.

452 (a) M Tišler and B. Stanovnik, Comprehensive Heterocyclic Chemistry, ed. A. R. Katritzky and C. W. Rees, Pergamon Press, Oxford, 1984, Vol. 3, p. 1; (b) W. J. Coates, Comprehensive Heterocyclic Chemistry, $2^{\text {nd }}$ ed. A. R. Katritzky, C. W. Rees and E. F. V. Scriven, Pergamon, Oxford, 1996, Vol. 6, p. 1

503 (a) R. A. Carboni and R. V. Lindsey, Jr., J. Am. Chem. Soc., 1959, 81, 4342-4346; (b) D. L. Boger, Chem. Rev., 1986, 86, 781-794.

4 A. W. Dox and L. Yoder, J. Am. Chem. Soc., 1922, 44, 361-366.

5 P. Molina, A. Arques, V. Vinader, J. Becher and K. Brondum, Tetrahedron Lett., 1987, 28, 4451-4454.

556 H. Bredereck, R. Gompper and H. Herlinger, Chem. Ber., 1958, 91, 2832-2849.

7 (a) G. W. H. Cheeseman and E. S. G. Werstiuk, Advances in Heterocycles Chemistry, Academic Press: New York, 1972, Vol. 14, p. 99; (b) G. B. Barlin, The Chemistry of Heterocyclic Compounds, Wiley: New York, 1982, Vol. 41.

8 G. Büchi and J. Galindo, J. Org. Chem., 1991, 56, 2605-2606.

9 C. Nájera, J. M. Sansano and M. Yus, Tetrahedron, 2003, 59, 92559303.

10 K. Shen, Y. Fu, J.-N. Li, L. Liu and Q.-X. Guo, Tetrahedron, 2007, $65 \quad \mathbf{6 3}, 1568-1576$.

11 T. Imahori and Y. Kondo, J. Am. Chem. Soc., 2003, 125, 8082-8083.

12 (a) G. Quéguiner, F. Marsais, V. Snieckus and J. Epsztajn, Adv. Heterocycl. Chem., 1991, 52, 187-304; (b) F. Mongin and G. Quéguiner, Tetrahedron, 2001, 57, 4059-4090; (c) M. Schlosser and F. Mongin, Chem. Soc. Rev., 2007, 36, 1161-1172.

13 (a) A. Turck, N. Plé, F. Mongin and G. Quéguiner, Tetrahedron, 2001, 57, 4489-4505; (b) A. Godard, A. Turck, N. Plé, F. Marsais and G. Quéguiner, Trends Heterocycl. Chem., 1993, 3, 16-29; (c) A. Turck, N. Plé and G. Quéguiner, Heterocycles, 1994, 37, 2149-2172.

7514 A. J. Clarke, S. McNamara and O. Meth-Cohn, Tetrahedron Lett., 1974, 15, 2373-2376.

15 M. Schlosser, O. Lefebvre and L. Ondi, Eur. J. Org. Chem., 2006, 1593-1598.

16 C. Berghian, M. Darabantu, A. Turck and N. Plé, Tetrahedron, 2005, 61, 9637-9644.

17 N. Plé, A. Turck, K. Couture and G. Quéguiner, J. Org. Chem., 1995, 60, 3781-3786.

18 A. Seggio, F. Chevallier, M. Vaultier and F. Mongin, J. Org. Chem., 2007, 72, 6602-6605.

8519 (a) A. Turck, N. Plé, V. Tallon and G. Quéguiner, Tetrahedron, 1995, 51, 13045-13060; (b) V. Gautheron-Chapoulaud, N. Plé and G. Quéguiner, Tetrahedron, 2000, 56, 5499-5507.

20 L. Decrane, N. Plé and A. Turck, J. Heterocyclic Chem., 2005, 42, 509-513.

9021 A. Turck, N. Plé, L. Mojovic and G. Quéguiner, J. Heterocyclic Chem., 1990, 27, 1377-1381.

22 F. Toudic, A. Turck, N. Plé, G. Quéguiner, M. Darabantu, T. Lequeux and J. C. Pommelet, J. Heterocycl. Chem., 2003, 40, 855860

9523 A. Turck, N. Plé, B. Ndzi, G. Quéguiner, N. Haider, H. Schuller and G. Heinisch, Tetrahedron, 1993, 49, 599-606.

24 A. Turck, N. Plé, L. Mojovic and G. Quéguiner, Bull. Soc. Chim. Fr. 1993, 130, 488-492.

25 (a) L. Mojovic, A. Turck, N. Plé, M. Dorsy, B. Ndzi and G. 100 Quéguiner, Tetrahedron, 1996, 52, 10417-10426; (b) N. Plé, A. Turck, K. Couture and G. Quéguiner, Synthesis, 1996, 838-842.

26 F. Trécourt, A. Turck, N. Plé, A. Paris and G. Quéguiner, J. Heterocycl. Chem., 1995, 32, 1057-1062.

27 V. Gautheron-Chapoulaud, I. Salliot, N. Plé, A. Turck and G. Quéguiner, Tetrahedron, 1999, 55, 5389-5404.

28 (a) R. J. Mattson and C. P. Sloan, J. Org. Chem., 1990, 55, 34103412; (b) J. J. Lee, S. H. Cho, Bull. Korean Chem. Soc., 1996, 17, 868-869; Chem. Abstr., 1996, 125, 300930h.

29 A. Turck, N. Plé, A. Leprêtre-Gaquère and G. Quéguiner, 110 Heterocycles, 1998, 49, 205-214.

30 A. Turck, N. Plé, P. Pollet, L. Mojovic, J. Duflos and G. Quéguiner, J. Heterocycl. Chem., 1997, 34, 621-627. 
31 A. Turck, N. Plé, P. Pollet and G. Quéguiner, J. Heterocycl. Chem., 1998, 35, 429-436.

32 P. Pollet, A. Turck, N. Plé and G. Quéguiner, J. Org. Chem., 1999, 64, 4512-4515.

533 N. Le Fur, L. Mojovic, N. Plé, A. Turck, V. Reboul and P. Metzner, J. Org. Chem., 2006, 71, 2609-2616.

34 N. Le Fur, L. Mojovic, N. Plé, A. Turck and F. Marsais, Tetrahedron, 2005, 61, 8924-8931.

35 A. Turck, N. Plé, L. Mojovic, B. Ndzi, G. Quéguiner, N. Haider, H. 10 Schuller and G. Heinisch, J. Heterocycl. Chem., 1995, 32, 841-846.

36 C. Fruit, A. Turck, N. Plé, L. Mojovic and G. Quéguiner, Tetrahedron, 2002, 58, 2743-2753.

37 A. Krasovskiy, V. Krasovskaya and P. Knochel, Angew. Chem., 2006, 118, 3024-3027; Angew. Chem. Int. Ed., 2006, 45, 2958-2961.

1538 (a) A. Busch, V. Gautheron-Chapoulaud, J. Audoux, N. Plé and A. Turck, Tetrahedron, 2004, 60, 5373-5382; (b) N. Le Fur, L. Mojovic, A. Turck, N. Plé, G. Quéguiner, V. Reboul, S. Perrio and P. Metzner, Tetrahedron, 2004, 60, 7983-7994.

39 T. J. Kress, J. Org. Chem., 1979, 44, 2081-2082.

2040 (a) R. Radinov, M. Haimova and E. Simova, Synthesis, 1986, 886891; (b) R. Radinov, C. Chanev, M. Haimova, J. Org. Chem., 1991, 56, 4793-4796.

41 N. Plé, A. Turck, P. Martin, S. Barbey and G. Quéguiner, Tetrahedron Lett., 1993, 34, 1605-1608.

2542 N. Plé, A. Turck, E. Fiquet and G. Quéguiner, J. Heterocyclic Chem., 1991, 28, 283-287.

43 (a) C. Párkányi, N. S. Cho and G. S. Yoo, J. Organomet. Chem., 1988, 342, 1-7; (b) M. Cushman, J. T. Mihalic, K. Kis, A. Bacher, J. Org. Chem., 1999, 64, 3838-3845.

3044 N. Plé, A. Turck, A. Heynderickx and G. Quéguiner, J. Heterocyclic Chem., 1994, 31, 1311-1315.

45 N. Plé, A. Turck, A. Heynderickx and G. Quéguiner, J. Heterocyclic Chem., 1997, 34, 551-556.

46 N. Plé, A. Turck, A. Heyndeickx and G. Quéguiner, Tetrahedron, $35 \quad$ 1998, 54, 9701-9710.

47 (a) A. Wada, J. Yamamoto and S. Kanatomo, Heterocycles, 1987, 26, 585-589; (b) A. Wada, J. Yamamoto, Y. Hamaoka, K. Ohki, S. Nagai and S. Kanatomo, J. Heterocycl. Chem., 1990, 27, 1831-1835.

48 (a) N. Plé, A. Turck, F. Bardin and G. Quéguiner, J. Heterocycl.

40 Chem., 1992, 29, 467-470; (b) N. Plé, A. Turck, K. Couture and G. Quéguiner, Tetrahedron, 1994, 50, 10299-10308.

49 W. Schwaiger and J. P. Ward, Recl. Trav. Chim. Pays-Bas, 1971, 90, 513-515.

50 G. P. Rizzi, J. Org. Chem., 1974, 39, 3598.

4551 (a) C. Fruit, A. Turck, N. Plé, L. Mojovic and G. Quéguiner, Tetrahedron, 2001, 57, 9429-9435; (b) F. Toudic, N. Plé, A. Turck and G. Quéguiner, Tetrahedron, 2002, 58, 283-293.

52 F. Buron, N. Plé, A. Turck and G. Quéguiner, J. Org. Chem., 2005, 70, 2616-2621.

5053 F. Toudic, A. Heynderickx, N. Plé, A. Turck and G. Quéguiner, Tetrahedron, 2003, 59, 6375-6384.

54 Y. Aoyagi, A. Maeda, M. Inoue, M. Shiraishi, Y. Sakakibara, Y. Fukui, A. Ohta, K. Kajii and Y. Kodama, Heterocycles, 1991, 32, 735-748.

5555 (a) A. Turck, L. Mojovic and G. Quéguiner, Synthesis, 1988, 881884; (b) A. Turck, N. Plé, D. Dognon, C. Harmoy and G. Quéguiner, J. Heterocyclic Chem., 1994, 31, 1449-1453; (c) W. Liu, J. A. Walker, J. J. Chen, D. S. Wise, B. L. Townsend, Tetrahedron Lett., 1996, 37, 5325-5328.

6056 (a) J. S. Ward and L. Merritt, J. Heterocycl. Chem., 1991, 28, 765768; (b) A. Turck, D. Trohay, L. Mojovic, N. Plé and G. Quéguiner, J. Organomet. Chem., 1991, 412, 301-310.

57 W. Liu, D. S. Wise, L. B. Townsend, J. Org. Chem., 2001, 66, $4783-$ 4786.

6558 A. Turck, N. Plé, V. Tallon and G. Quéguiner, J. Heterocycl. Chem., 1993, 30, 1491-1496.

59 N. Plé, A. Turck, A. Heynderickx and G. Quéguiner, Tetrahedron, 1998, 54, 4899-4912.

60 C. Berghian, E. Condamine, N. Plé, A. Turck, I. Silaghi-Dumitrescu, 70
61 C. Y. Zhang and J. M. Tour, J. Am. Chem. Soc., 1999, 121, 87838790 .

62 A. Turck, N. Plé, D. Trohay, B. Ndzi and G. Quéguiner, J. Heterocycl. Chem., 1992, 29, 699-702.

7563 C. Fruit, A. Turck, N. Plé and G. Quéguiner, Heterocycles, 1999, 51, 2349-2365.

64 R. Chinchilla, C. Nájera and M. Yus, Chem. Rev., 2004, 104, 26672722. 